\title{
A Miocene age for the Molo Formation, Norwegian Sea shelf off Vestfjorden, based on marine palynology
}

\author{
Kari Grøsfjeld' , Karen Dybkjær ${ }^{2}$, Tor Eidvin ${ }^{3}$, Fridtjof Riis ${ }^{3}$, Erik Skovbjerg Rasmussen ${ }^{2} \&$ \\ Jochen Knies ${ }^{1,4}$
}

${ }^{1}$ Geological Survey of Norway, P.O. Box 6315 Torgarden, N-7491 Trondheim, Norway.

${ }^{2}$ Geological Survey of Denmark and Greenland (GEUS), Øster Voldgade 10, DK-1350 Copenhagen K, Denmark.

${ }^{3}$ Norwegian Petroleum Directorate (NPD), Professor Olav Hanssens vei 10, NO-4021 Stavanger, Norway.

${ }^{4}$ Centre for Arctic Gas Hydrate, Environment and Climate, University of Troms $\emptyset$, N-9037 Tromsø, Norway.

E-mail corresponding author (Kari Grøsfjeld): kari.grosfjeld@ngu.no

Seven side-wall core samples from the lower part of the Molo Formation in exploration well 6610/3-1 off Vestfjorden/Lofoten have been reanalysed for marine palynomorphs. Description of new species from other studies and access to reference successions from nearby sites with an independent chronostratigraphy have enabled a more reliable depositional age constraint for the Molo Formation in its northern distribution area than previously achieved. The new data (e.g., the lowest occurrence of the dinoflagellate cysts Barssidinium graminosum and Barssidinium pliocenicum and the highest occurrence of the dinoflagellate cysts Minisphaeridium latirictum and Operculodinium piaseckii) provide incontrovertible evidence for a Miocene age for the Molo Formation in well 6610/3-1. Our data suggest that the Molo Formation in well 6610/3-1 started to accumulate after erosional activity which took place between the late middle Miocene and the late Miocene. The data (especially the presence of the dinoflagellate cyst $A$. andalouisiensis andalousiensis, the co-occurrence of the dinoflagellate cysts Barssidinium evangelineae and M. latirictum and the presence of the acritarch L. lucifer) suggest that the Molo Formation in well 6610/3-1 started to accumulate at around 8.8 / 8.7 Ma. The sediments were deposited in a warm temperate, high-energy environment influenced by river discharge. During deposition, older sediments, particularly from the Paleogene, became extensively eroded. The erosion and rapid accumulation were probably associated with the combined effects of eustatic sea-level fall and uplift/updoming of the hinterland/coastal zone.

Keywords: Molo Formation, Eastern Norwegian shelf, Biostratigraphy, Dinoflagellate cysts, Miocene

Electronic Supplement 1: Raw data

Received 8. January 2019 / Accepted 12. August 2019 / Published online 10. December 2019

\section{Introduction}

The origin and deposition of the shallow-marine coastparallel Molo Formation, extending for at least $600 \mathrm{~km}$ along the middle/inner continental shelf $\left(63^{\circ} 15^{\prime} \mathrm{N}\right.$ to $67^{\circ} 50^{\prime} \mathrm{N}$ ) (Henriksen \& Vorren, 1996; Løseth et al., 2017), has repeatedly been a subject for discussion (Fig. 1). Particularly its time of deposition and source of accumulation have been extensively debated. The Molo Formation was first recognised and mapped by Eldholm \& Nysæther (1968) and Nysæther et al.
(1969), but it has still not been formally defined by the Norwegian Stratigraphic Committee. Description of a new lithostratigraphic nomenclature for the post-Eocene deposition on the Norwegian continental shelf is under preparation. Originally, all shallow westward-prograding sands above deposits interpreted to be of Eocene age on the inner continental shelf offshore Møre to Lofoten, between $63^{\circ} 15^{\prime} \mathrm{N}$ and $67^{\circ} 50^{\prime} \mathrm{N}$, were defined as belonging to the Molo Formation depositional system (Eidvin et al., 2013). Bugge et al. (1976) were among the first to propose that the Molo Formation was deposited as a result of uplift and erosion of the mainland.

Grøsfjeld, K., Dybkjær, K., Eidvin, T., Riis, F., Rasmussen, E.S. \& Knies, J. 2019: A Miocene age for the Molo Formation, Norwegian Sea shelf off Vestfjorden, based on marine palynology. Norwegian Journal of Geology 99, 1-20. https://dx.doi.org/10.17850/njg99-3-6. 


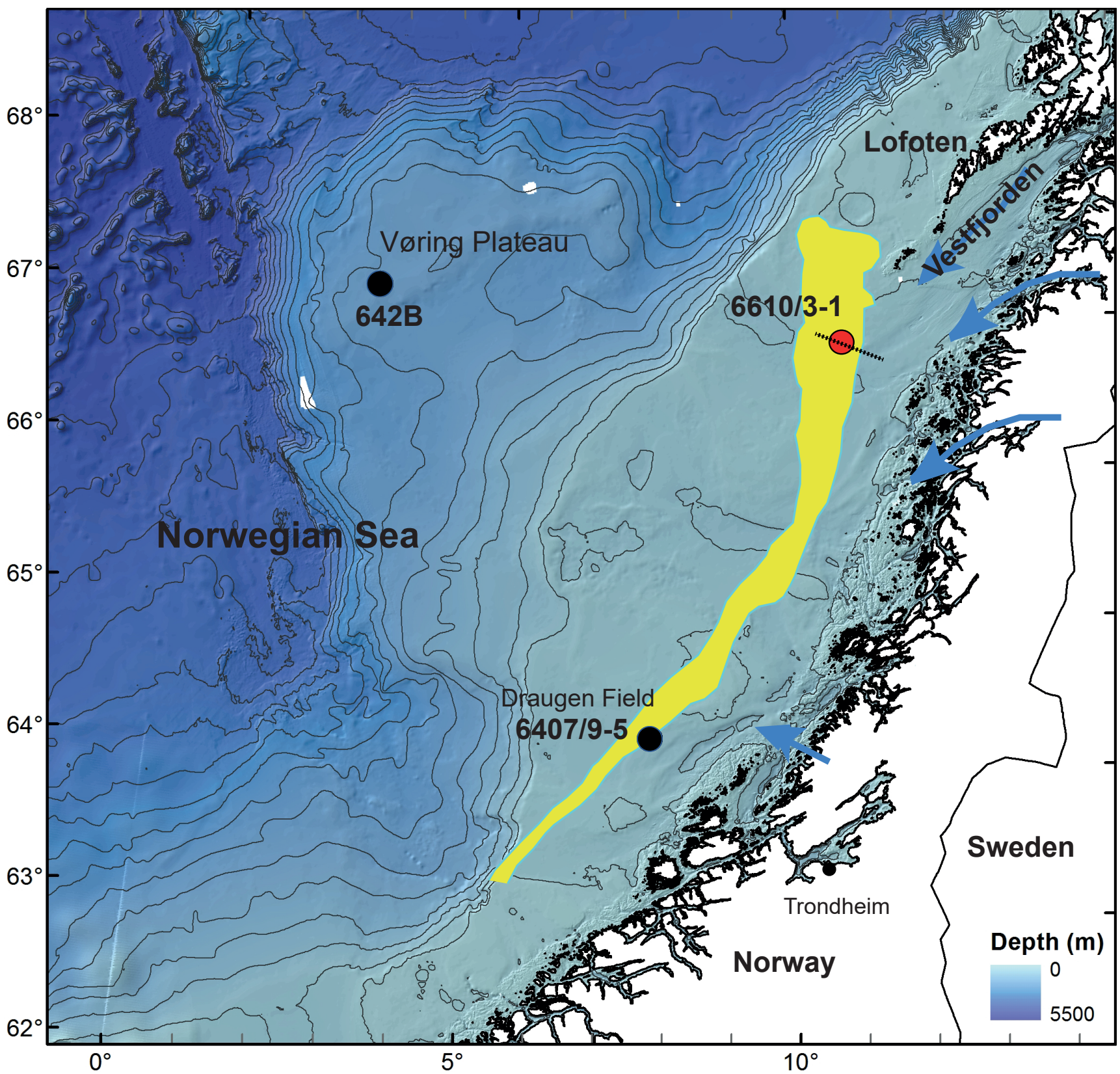

Figure 1. Bathymetric map with location of the investigated well 6610/3-1 (Nordland Ridge) outside Vestfjorden. The locations of Ocean Drilling Program (ODP) Hole 642B on the outer shelf (Vøring Plateau) and well 6407/9-5 on the Draugen Field (Trøndelag Platform) are also shown. The sea-bottom outcrop of the Molo Formation (outline), after Ottesen et al. (2009), is indicated in yellow. The paleocoast during deposition of the Molo Formation was likely located east of the eastern boundary of this outcrop. The location of the seismic profile (stippled line) crossing well 6610/3-1 is also shown (see Fig. 2). Blue arrows show possible drainage routes along old lineaments at the time when the Molo Formation was deposited.

The lithology of the Molo Formation varies throughout its distribution area. Whereas the deposits in the north consist of clastic sandy sediments with minor glauconite, the sands in the south (Draugen Field area) are dominated by dark glauconite grains, with minor clay and silt (Fig. 1; Eidvin et al., 2007, 2013). The sands in the north are considered to be sourced from the Vestfjorden area in the northeast. The clastic sediments apparently did not reach as far south as the Draugen Field area. There appears to be consensus with regard to the depositional environment. The Molo Formation represents a prograding, marine, shelf-edge delta influenced by waves and currents and extensive longshore drift (Rokoengen et al., 1995). Both its sandy lithology and the characteristic seismic reflection pattern with densely spaced, steeply dipping (up to 15 degrees) clinoforms (Fig. 2; Rokoengen et al., 1995; Patruno \& Helland-Hansen, 2018) are evidence of a high-energy coastal environment. The top-set beds are commonly missing in the inner part, possibly due to erosion, whereas top sets and bottom sets are normally preserved in the outer part (Løseth et al., 2017). In its northern distribution area the sandy unit is a wave breaker being nearly exposed on the seabed. 


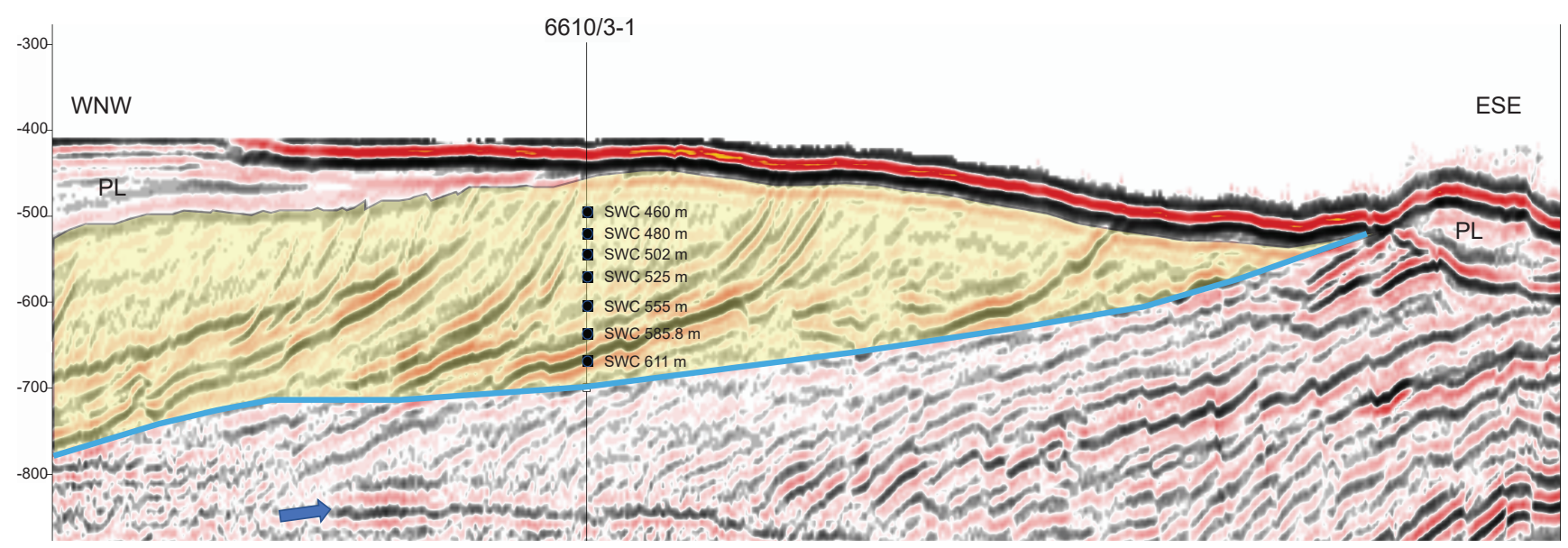

Figure 2. A WNW-ESE, fifteen km-long, seismic profile through exploration well 6610/3-1 (see Fig. 1 for its geographical location), showing the westward prograding Molo Formation (Fm) (indicated in yellow) on the Norwegian shelf. The well penetrates an upward-coarsening sequence of the Molo Fm from distally deposited sediments through sandy steep clinoforms in the upper part. The unconformity at the base of the Molo Fm sequence is indicated by the blue line. Seven side-wall cores (SWCs) collected from the Molo Formation have been marine-palynologically reinvestigated. The SWCs located at 611 and $585.8 \mathrm{~m}$ were collected from the fine-grained sediments. The SWCs at 525 and $555 \mathrm{~m}$ are from the grey, mica-rich, sand layers below the clinoforms, whereas the SWC at $502 \mathrm{~m}$ was collected immediately below the clinoforms. The SWCs at 460 $m$ and $480 \mathrm{~m}$ are from the lower part of the steep clinoforms (rust-stained sand and pebbles). The reflector hosting the samples at $611 \mathrm{~m}$ and $585.8 \mathrm{~m}$ climb into the prograding succession eastwards, indicating that the onset of the progradation is likely older than the age constrained for the Molo Formation in well 6610/3-1. Due to the erosional truncation of the Molo Fm towards the east, the onset of the progradation of the Molo Fm and its oldest shoreline are not preserved. The depths are in milliseconds two-way travel time, and all depths refer to metres below the rig floor (m). A sea-floor multiple is indicated by the blue arrow. Abbreviation: PL - Pleistocene sediments.

Due to the lack of reliable age constraints, the erosional and depositional history of the Molo Formation is poorly understood. For example, the suggested age of the Molo Formation in the north off Vestfjorden/Lofoten has varied considerably from between Rupelian (early Oligocene) (Eidvin et al., 1998, 2014) to the post midMiocene compression phase (Eidvin et al., 2007), as well as the Zanclean (early Pliocene) (Henriksen \& Vorren, 1996; Løseth et al., 2017). The thickness of the Molo Formation varies significantly, being thickest close to its northern limit, where its depocentre is located. It has been suggested that the Molo Formation coastal sand in its northern distribution area (off Vestfjorden/Lofoten) was deposited at an earlier stage than the sand in the south (Eidvin et al., 2013, 2014).

Based on analyses of foraminifera, dinoflagellate cysts and strontium isotope stratigraphy, Eidvin et al. (2007) investigated the Molo Formation sand in its southern distribution area. One of their studied sections was from exploration well $6407 / 9-5$, on the Draugen Field Trøndelag Platform, in the Norwegian Sea (Fig. 1). There, the Molo Formation accumulated in a distal position from the palaeo-coastline. It was interpreted to have been deposited during the late Miocene with continued deposition into the early Pliocene (Eidvin et al., 2007). The exploration well 6610/3-1, which has been restudied in the present study, is located close to the northern boundary of the Molo Formation and its depocentre in the north. Here, the Molo Formation was deposited in a proximal location from the palaeo-coastline. From this well, Eidvin et al. (1998) published dinoflagellate cyst results from the lower part of the Molo Formation, which included five side-wall cores from 460 to 555 metres below the rig floor (mRKB, hereafter referred to as $\mathrm{m}$ ). Based on analyses of foraminifera, dinoflagellate cysts and strontium-isotope stratigraphy, Eidvin et al. (1998) concluded with a Rupelian age for the Molo Formation. Eidvin et al. (2007) reinvestigated the same samples from the Molo Formation. In addition, they carried out dinoflagellate cyst analyses on samples from the section immediately below the Molo Formation. These include the samples at $589.8 \mathrm{~m}$ and $611 \mathrm{~m}$, which they defined to belong to the Brygge Formation. Based on seismic interpretation and regional considerations, Eidvin et al. (2007) favoured a post mid-Miocene age for the Molo Formation in its northern distribution area (Fig. 3). For the samples immediately below the Molo Formation, Eidvin et al. (2007) reported a rich and relatively diverse marine microflora including several typical Eocene species and reworked Jurassic dinoflagellate cysts. They interpreted these samples to be of Bartonian (middle Eocene) age and included them in the Brygge Formation. Eidvin et al. $(2013,2014)$ returned to the previous interpretation of a Rupelian age for the Molo Formation. Based on interpretation of new seismic data, Eidvin et al. (2013) correlated well 6610/3-1 with well 6610/2-1 S, which is located southwest of well $6610 / 3-1$ on the Nordland Ridge and in a more distal position from the coast than well 6610/3-1 (see Eidvin et al., 2013 for its location). The Molo Formation in well 6610/2-1 S was interpreted to have accumulated during the early 


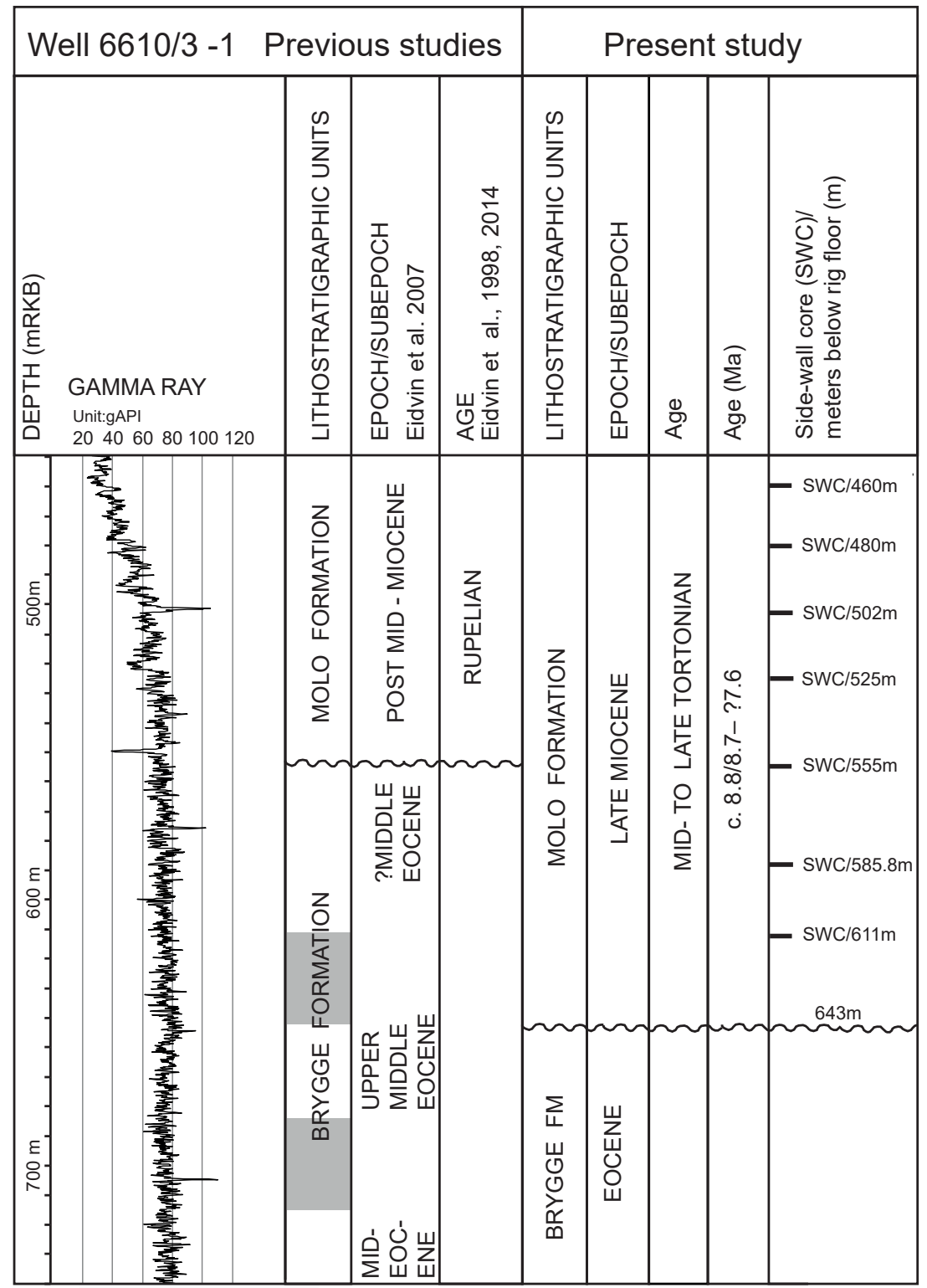

Sea floor $=332$ metres below rig floor $(m R K B)$

Figure 3. Gamma ray, lithostratigraphy and previous (Eidvin et al., 1998, 2007, 2014) and current age assignment based on the reinvestigation of the seven side-wall cores located between 611 and $460 \mathrm{~m}$ in exploration well 6610/3-1. The redefined age of the location of the base of the Molo Fm at 643 $m$ is based on the new age constraints and compilation of logs and seismics. As the Molo Formation appears to have started to prograde farther east of well 6610/3-1 (see Fig. 2), the constrained age for the Molo Formation strictly holds only for the well section of 6610/3-1. The constrained age is based on Cohen et al. (2013, updated 2018). Modified from Eidvin et al. (2007). Abbreviations: B - Brygge; Fm - Formation; SWC - side-wall core; gAPI American Petroleum Institute gamma-ray units, $\mu \mathrm{s} / \mathrm{f}=$ microseconds per foot. All depths $(\mathrm{m})$ refer to metres below the rig floor $(\mathrm{mRKB})$.

Oligocene. They considered the Rupelian taxa in well 6610/3-1 to be indigenous and the Molo Formation in this location to be equivalent to the Brygge Formation. Further, they interpreted the Molo Formation to be younger towards the west and south.

The difficulties in constraining a reliable age for the Molo Formation are multifaceted. In both exploration wells $6610 / 3-1$ and 6407/9-5 the marine palynomorphinferred ages have been based on the age ranges of species living in other areas. Several species have recently been shown to have a diachronous distribution across various basins (De Schepper et al., 2015, 2017).
Reliable age constraints depend on either a detailed chronostratigraphy in the studied section (for example based on palaeo-magnetostratigraphy) or access to reference sections located nearby with ages based on calibrated bioevents. An additional problem is that samples from exploration wells, where only ditchcutting samples are routinely available, suffer from contamination by caved fossils. This precludes a reliable detection of the lowest occurrence (LO) of a species. In contrast to exploration well $6407 / 9-5$, which was sampled only with ditch cuttings in the Molo section, well 6610/3-1 was sampled with high-quality side-wall cores in its upper part including the Molo Formation 


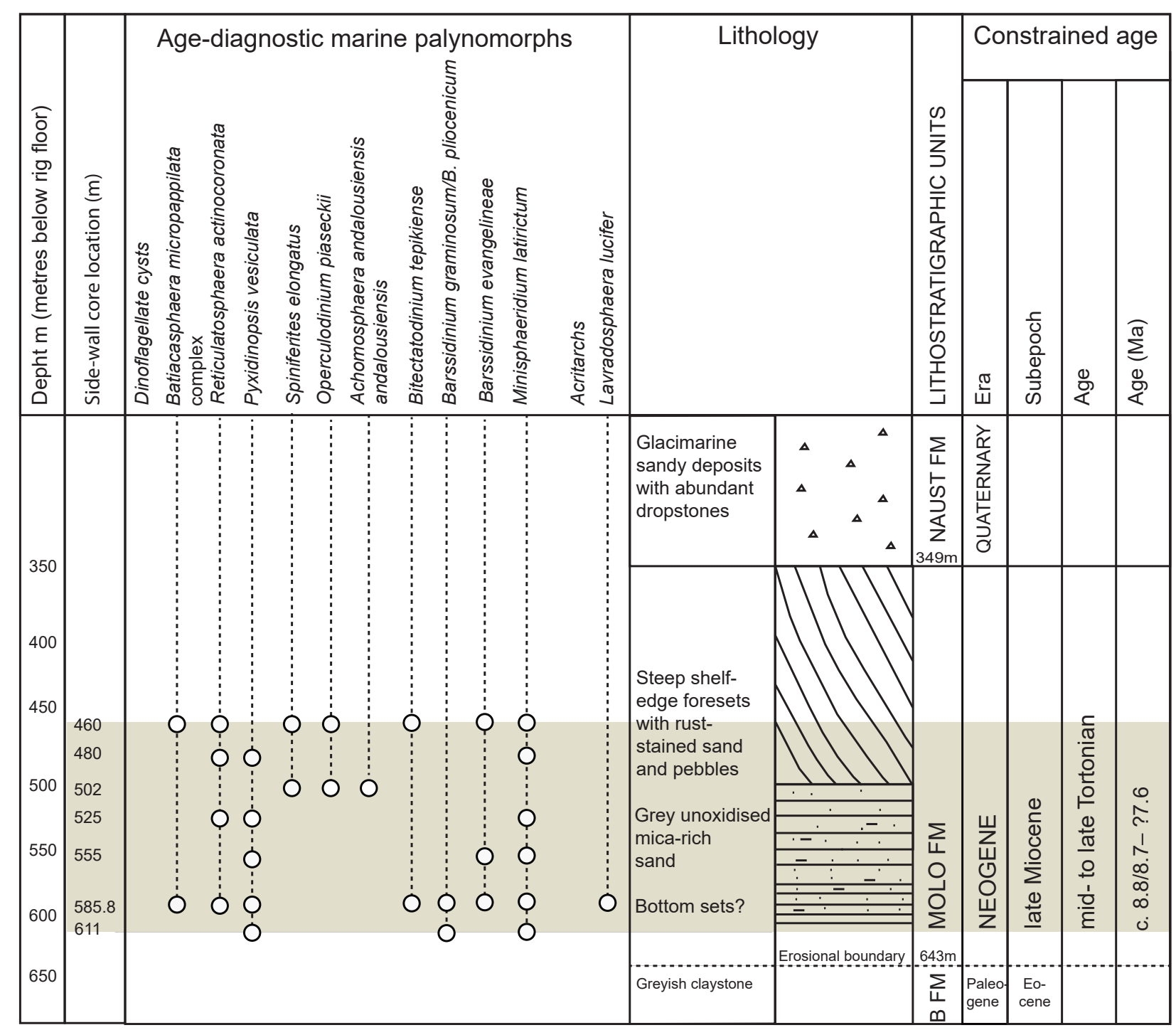

Sea floor $=332$ metres below rig

Figure 4. Litho-, bio- and chronostratigraphy of well 6610/3-1. The constrained mid-to late-Tortonian age of the Molo Formation is based on the stratigraphic distribution of index taxa (dinoflagellate cysts and acritarchs, see Fig. 8 and Table 3) between 611 and $460 \mathrm{~m}$ in the Molo Formation (Fm). The lowermost reinvestigated side-wall core sample (SWC) at $611 \mathrm{~m}$ is located $32 \mathrm{~m}$ above the base of the Molo Fm. Both SWC samples at 611 and 585.8 $m$ were collected from the finer-grained deposits in the lower part of the Molo Fm. The SWC samples at $555 \mathrm{~m}$ to $502 \mathrm{~m}$ are from the deposits below the steep clinoforms, whereas the SWC samples at 480 and $460 \mathrm{~m}$ are from the lower part of the steep clinoforms. The investigated part of the sequence is highlighted. The age is based on Cohen et al. (2013, updated 2018). Abbreviations: B - Brygge, Fm - Formation, $m$ - metres below the rig floor.

(Fig. 4). On the other hand, the succession referred to the Molo Formation in well 6610/3-1 contains distinctly larger amounts of reworked material than the Molo Formation deposits in well 6407/9-5. This is likely due to the more proximal location of well 6610/3-1 compared with well 6407/9-5. In well 6610/3-1, extensive reworking of older deposits in the source area has caused dilution of the indigenous taxa by an ample supply of reworked taxa. This has complicated the age constraint on the Molo Formation in its northern distribution area.

Since the last palynological investigation of the Molo Formation, there has been considerable progress in marine palynomorph biostratigraphy. An up-todate Messinian to Piacenzian marine palynomorph biozonation has recently been established for Ocean Drilling Program (ODP) Hole 642B, on the outer shelf (Vøring Plateau) in the eastern Norwegian Sea (De Schepper et al., 2015, 2017), relatively close to well 6610/3-1 (Figs. 2 \& 3). Another section with wellconstrained bioevents is ODP Site 907, located in the Iceland Sea at about the same latitude as well 6610/3-1 (Figs. 2 \& 3; Schreck et al., 2012). Combined with the description of many new marine palynomorph taxa, including dinoflagellate cysts and acritarchs in recent years (De Schepper \& Head, 2008a, 2014; Schreck et al., 
Table 1. Reanalysed samples/slides in exploration well 6610/3-1 with references to the slides. All depths $(m)$ refer to metres below the rig floor.

\begin{tabular}{|c|c|c|c|c|}
\hline $\begin{array}{l}\text { Latitude } \\
66^{\circ} 55^{\prime} 29.70^{\prime \prime} \mathrm{N}\end{array}$ & $\begin{array}{l}\text { Longitude } \\
10^{\circ} 54^{\prime} 6.28^{\prime \prime} E\end{array}$ & & & \\
\hline Sample depth (m) & Sample type & Owner & Slide ref. & Slide \\
\hline 460 & Side wall core (SWC) & NPD & P-51419 & $460 \mathrm{~m} \varnothing 1$ \\
\hline 480 & Side wall core (SWC) & NPD & P-51420 & $480 \mathrm{~m} \varnothing 1$ \\
\hline 502 & Side wall core (SWC) & NPD & P-51421 & $502 \mathrm{~m} \varnothing 1$ \\
\hline 525 & Side wall core (SWC) & NPD & $\mathrm{P}-51422$ & $525 \mathrm{~m} \varnothing 1$ \\
\hline 555 & Side wall core (SWC) & NPD & P-51423 & $555 \mathrm{~m} \varnothing 1$ \\
\hline 585.8 & Side wall core (SWC) & Statoil & Statoil & $585.8 \mathrm{mX}$ \\
\hline 611 & Side wall core (SWC) & Statoil & Statoil & $611 \mathrm{mX}$ \\
\hline
\end{tabular}

2012; De Schepper et al., 2015, 2017), this has increased the potential to obtain more reliable depositional age constraints on the Molo Formation.

On the basis of the recent progress in marine palynomorph biostratigraphy, we have reanalysed marine palynomorphs aiming to obtain an improved age constraint on the Molo Formation and its erosional history in its northern distribution area. Sample preparation (slides) from seven side-wall cores in well 6610/3-1 have been reanalysed (Table 1). These include seven samples from the lower part of the Molo Formation (Fig. 2).

\section{Geological setting}

The Norwegian Sea formed the eastern part of the North Atlantic realm during the Paleogene (Eidvin et al., 2014). It was bounded towards the east by the Fennoscandian Shield. However, the exact location of the shoreline is unknown. The Norwegian Sea was dominated by hemipelagic mud deposition during the Paleogene. A major unconformity formed at the end of the Paleogene or during the early part of the Neogene. This unconformity separates the lower Brygge Formation from the upper Brygge Formation (Eidvin et al., 2007). However, the fully marine depositional setting, characterised by hemipelagic mud sedimentation, continued during the early Miocene (i.e., the early part of the Neogene). A second important erosional break, referred to as the middle Miocene unconformity, exists in the northern North Sea and on the Norwegian Sea shelf (Brekke, 2000; Eidvin \& Rundberg, 2007; Eidvin et al., 2007, 2013, 2014).

Detailed seismic attribute studies of the clinoformal package in the Molo Formation indicates a depositional environment with deltas and barrier-island complexes (Bullimore et al., 2005; Løseth et al., 2017). Thus, the lithology of the clinoformal units is inferred to be dominated by sands intercalated with marine and lagoonal muds. However, the lithology of the Molo Formation varies throughout its distribution area. For instance, the lithology in the north consists of clastic sandy sediments with minor glauconite, whereas the sands in the south (Draugen Field area) are dominated by dark glauconite grains, with minor clay and silt (Fig. 1; Eidvin et al., 2007, 2013, 2014). The sands in the north are considered to be sourced from the Vestfjorden area in the northeast. The ancient Vestfjorden lineament (fracture zone), has been reactivated several times since the Paleocene. This old lineament probably served as a transport system or corridor for delivery of sediments to the shelf. The clastic sediments apparently did not reach as far south as the Draugen Field area. There, the glauconite must have been formed on the sea floor, later to become transported and sorted along the coast.

\section{Material and methods}

\section{Material}

Well 6610/3-1 was drilled at 6655'29.70”N, 1054'6.28”E in the southern Vestfjorden Basin on the Nordland ridge and penetrates the Molo Formation (Figs. 1 \& 2). Eidvin et al. (1998, 2007, 2014) defined the Molo Formation to comprise the interval from 555 to $c .349 \mathrm{~m}$. The basal/lower boundary of the Molo Formation was placed at approximately $555 \mathrm{~m}$ by Eidvin et al. (2007), being marked by a strong negative spike on the gamma $\log$ (Fig. 3). The finer-grained deposits below $555 \mathrm{~m}$ were included in the Brygge Formation (Eidvin et al., 1998, 2007). However, in the current study, on the basis of the current age constraints and compilation of logs and seismics, the base of the Molo Formation has been shifted stratigraphically further down to $643 \mathrm{~m}$ (Fig. 4). The Molo Formation is overlain by a thin cover of glaciomarine sediments of the Naust Formation. The upper boundary of the Molo Formation has not been sampled and logged at this site. It is only recognised on seismic lines (Eidvin et al., 2007). 
Five side-wall cores (at $611 \mathrm{~m}, 585.8 \mathrm{~m}, 555 \mathrm{~m}, 525 \mathrm{~m}$ and $502 \mathrm{~m}$ ) collected in the lower part of the analysed section below the clinoforms, and two samples (at 480 $\mathrm{m}$ and $460 \mathrm{~m}$ ), collected in the lower part of the steep clinoforms, have been reanalysed (Figs. 2 \& 4). The characteristics of the finer-grained sediments in the two lowermost analysed samples (at $611 \mathrm{~m}$ and $585.8 \mathrm{~m}$ ), previously included in the Brygge Formation, are not known in detail. The samples at $555 \mathrm{~m}, 525 \mathrm{~m}$ and $502 \mathrm{~m}$ consist of grey, unoxidised, mica-rich sand. In contrast, the samples from the clinoforms (at $460 \mathrm{~m}$ and $480 \mathrm{~m}$ ) contain mostly quartzose sand with pebbles and only minor glauconite. The quartz grains have a rust-stained and oxidised appearance. Rounded and subrounded, rust-tinted pebbles of crystalline rocks are also present.

\section{Processing and analysis}

\section{Processing techniques}

The samples from 555-460 m were carefully cleaned of any adherent solidified drilling mud ('mud cake') and their quality assessed. Unfortunately, there is no information about how the two lowermost side-wall cores (at $611 \mathrm{~m}$ and $585.8 \mathrm{~m}$ ) were treated after they were collected.

The samples from 460 to $555 \mathrm{~m}$ were processed at the laboratory of the Norwegian Petroleum Directorate (NPD). Of $10-30 \mathrm{~g}$ of sediment sampled from the sidewall cores, the material smaller than $0.1 \mathrm{~mm}$ was saved for palynological analysis (Eidvin et al., 1998). Acid digestion applying HCL and HF was carried out to remove carbonate and silicate particles, respectively. Unconsolidated sediment was soaked in water and wet sieved, whereas consolidated sediment was dissolved in hydrogen peroxide. Cold (50\%) nitric acid $\left(\mathrm{HNO}_{3}\right)$ was applied for 2 minutes to oxidise the residue in order to remove pyrite and some amorphous organic material. The residues were sieved through a 20 microns mesh. In spite of this relatively large mesh size, with the possibility of losing small and potentially stratigraphically useful acritarchs, several small marine palynomorphs with a diameter less than 20 micron were recovered. The residues were mounted on cover slips using the mounting medium Elvacite. The two lowermost samples from 585.8 and $611 \mathrm{~m}$ were processed by Statoil. The processing technique of these two samples is not known in detail, but conventional preparation methods were followed.

\section{Analysis}

The main focus has been to constrain the age of the Molo Formation based on the presumed in situ dinoflagellate cysts and acritarchs. It is not intended to provide a detailed description of the marine palynomorph assemblages as the main part is reworked. For this purpose, the slides from the seven side-wall cores (SWC) of well $6610 / 3-1$ were scanned to search for potential age-significant marine palynomorphs (Table 1). The number of marine palynomorphs counted in each sample varies between 132 and 299 specimens (Electronic Supplement 1). For identification, a 63x/1.40 Zeiss oil immersion objective on a Zeiss Axioplan microscope was applied. The recorded specimens are listed in Table 2. The potential age-diagnostic taxa are illustrated in Figs. 5-7. Dinoflagellate cyst and acritarch nomenclature follows Châteauneuf (1980), Head et al. (1989b), Manum et al. (1989), De Schepper \& Head (2008a) and Williams et al. (2017).

All absolute ages in the present study are based on Cohen et al. (2013, updated 2018).

\section{Taxonomic note}

Barssidinium evangelineae. The specimens we have attributed to $B$. evangelineae correspond to the description of this species by Lentin et al. (1994), by having short, hollow, aculeate processes which are open distally (Fig. 5, photos 2-4). One of the criteria to differentiate $B$. evangelineae from Barssidinium pliocenicum and Barssidinium graminosum is that the processes are open distally. The processes also have annular thickenings (or septa). The process length/ central body length ratio falls within the range described for the species, which is one seventh to one tenth (Fig. 5 , photo 4). The smooth to psilate wall sculpturing also agrees with that described for the species, which can be smooth to densely granulate. However, our specimens differ from the description of this species by being considerably smaller. We attribute the small size to the adverse environmental conditions at the site, which are described below.

Batiacasphaera micropapillata complex. De Schepper et al. (2017) included specimens with a microreticulate wall as well as specimens with other types of wall ornamentation in their Batiacasphaera micropapillata complex. In Schreck et al. (2012), specimens with a microreticulate wall are included in Batiacasphaera micropapillata. The taxa included in our Batiacasphaera micropapillata complex have microreticulate wall ornamentation.

Bitectatodinium tepikiense. A specimen of B. tepikiense with a single plate lost in the archeopyle was recorded at $460 \mathrm{~m}$ (Fig. 5, photo 17). The number of opercular plates lost in the archeopyle is one of several criteria used to differentiate between genera. For example, Habibacysta tectata and B. tepikiense have been differentiated by the presence of a one- or two-plate archeopyle (Head, 1994 and references therein). B. tepikiense is a species with a two-plate archeopyle. Thus, B. tepikiense specimens with only one of the plates lost in the archeopyle may 
Table 2. List of taxa. This includes all the recorded marine palynomorphs which could be identified to species or generic level. The nomenclature refers to Williams et al. (2017).

Neogene taxa
Dinoflagellate cysts
Achomoshaera andalousiensis
andalousiensis
Barssidinium evangelineae
Barssidinium graminosum
Barssidinium pliocenicum
Bitectatodinium tepikiense
Minisphaeridium latirictum
Operculodinium piaseckii
Pyxidinopsis vesiculata
Spiniferites elongatus
Acritarchs
Lavradosphaera lucifer

\begin{tabular}{l} 
Potential Neogene taxa \\
Dinoflagellate cysts \\
cf. Capillicysta fusca \\
Operculodinium sp. \\
Pyxidinopsis sp. \\
Quinquecuspis sp. \\
cf. Sumatradinium pustulosum \\
Acritarchs \\
cf. Cymatiosphaera? spp. \\
cf. Cyclopsiella granosa \\
\hline
\end{tabular}

\section{Long ranging taxa}

Dinoflagellate cysts

Batiacasphaera micropapillata complex

Dapsilidinium pseudocolligerum/pastielsii

Distatodinium paradoxum

Hystrichokolpoma cinctum

Hystrichokolpoma rigaudiae

Lingulodinium machaerophorum

Operculodinium centrocarpum
Operculodinium israelianum

Operculodinium spp.

Palaeocystodinium golzowense

Reticulatosphaera actinocoronata

Spiniferites mirabilis

Spiniferites pseudofurcatus

Spiniferites pseudofurcatus verrucosus

Spiniferites ramosus

Spiniferites spp.

Tectatodinium pellitum

Thalassiphora pelagica

Acritarchs

Tectatodinium sp. 1 Manum, 1976

Problematicum III Manum 1976

\section{Paleogene taxa}

Dinoflagellate cysts

Achomosphaera ramulifera

Achilleodinium biformoides

Areosphaeridium diktyoplokum

Areosphaeridium michoudii

Axiodinium augustum

Caligodinium amiculum

Cerebrocysta bartonensis

Charlesdowniea spp.

Cleistosphaeridium spp.

Cordosphaeridium cantharellus

Cordosphaeridium funiculatum

Cordosphaeridium fibrospinosum

Corrudinum incompositum

Cribroperidinium giuseppei

Deflandrea granulata

Deflandrea phosphoritica

Dinopterygium cladoides

Diphyes colligerum
Distatodinium ellipticum

Elytrocysta brevis

Enneadocysta arcuata/E. pectiniformis

Evittosphaerula sp.

Glaphyrocysta semitecta

Heteraulacysta leptaea

Heteraulacysta porosa

Hystrichosphaeridium tubiferum

Hystrichostrogylon membraniphorum

Lanternosphaeridium lanosum

Licracysta semicirculata

Membranosphaera sp. B de Coninck 1975

Microdinium sp. 1 of Châteauneuf (1980)

Operculodinium divergens

Palaeoperidinium pyrophorum

Phthanoperidinium amoenum/P. regalis

Phthanoperidinium comatum

Phthanoperidinium echinatum

Phthanoperidinium levimurum

Rhombodinium draco

Rotnestia borussica

Samlandia chlamydophora

Spinidinium densispinatum

Spiniferella cornuta cornuta

Spiniferites sp. 2 of Manum et al. 1989

Svalbardella cooksoniae

Thalassiphora delicata

Thalassiphora fenestrata

Wetzeliella articulata

Wetzeliella spp.

Acritarchs

Cordosphaeridium callosum

\section{Green algae}

Botryococcus

Figure 5-7. (Page 9-11)

Selected marine palynomorphs recorded in well 6610/3-1. Figs. 5 \& 6 illustrate the marine palynomorphs used to constrain the age, whereas Fig. 7 illustrates dinoflagellate cyst taxa which are characteristic for the environment and/or which could not be identified to species level. All photomicrographs are in bright field illumination. Where several focal levels are included these are successively from high to low level. All scale bars are 20 microns. For each illustrated specimen the depth in metres below the sea floor $(m=m R K B)$ and the location of the specimen on the slide, i.e., the England Finder coordinates (E.F.) are provided. References to the analysed slides are included in Table 1. 

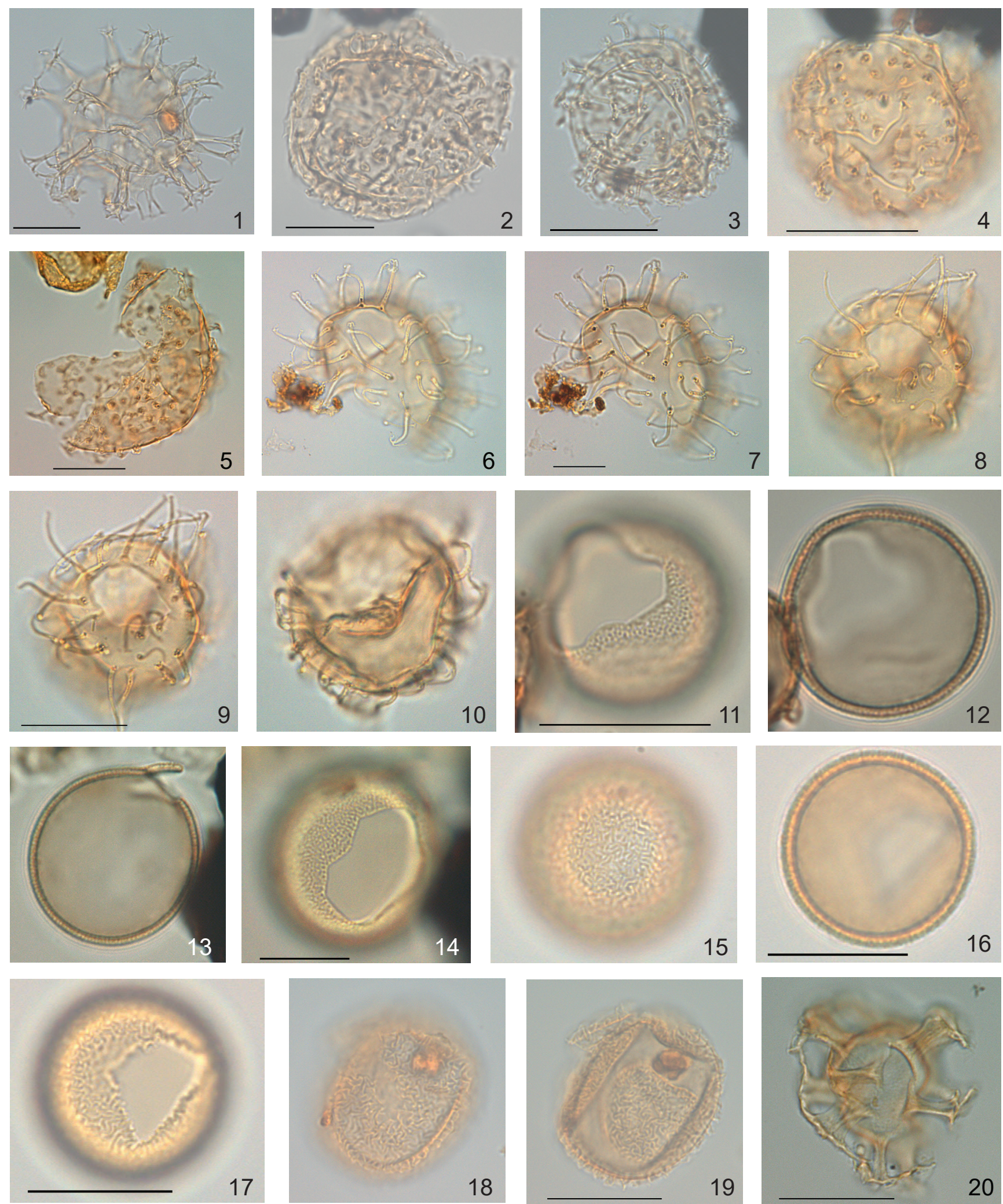

Figure 5. Marine palynomorphs

Dinoflagellate cysts

Acomosphaera andalousiensis andalousiensis

1. Well 6610/3-1, 502 m, E.F. Y59.

Barssidinium evangelineae

2. Well 6610/3-1, 460 m, E.F. X62/2.

3. Well $6610 / 3-1,555 \mathrm{~m}$ E.F. U24/2.

4. Well 6610/3-1, $585.8 \mathrm{~m}$, E.F. S65/4.
Barssidinium pliocenicum

5. Well 6610/3-1, 585.8 m, E.F. U63/4.

Barssidinium graminosum

6, 7. Well 6610/3-1, 611 m, E.F. T67/3.

8-10. Well 6610/3-1, 611 m, E.F. T70/2.

Batiacasphaera micropapillata complex

11, 12. Well 6610/3-1, 460 m, E.F. S15.

13, 14. Well 6610/3-1, 460 m, E.F. V57/3.
Bitectatodinium tepikiense

15-17. Well 6610/3-1, 460 m, E.F. U35/1. Only one of the two plates in the archeopyle is lost.

18, 19. Well 6610/3-1, 585.8 m, E.F. W62/1.

Minisphaeridium latirictum

20. Well 6610/3-1, 611 m, E.F. V37. 

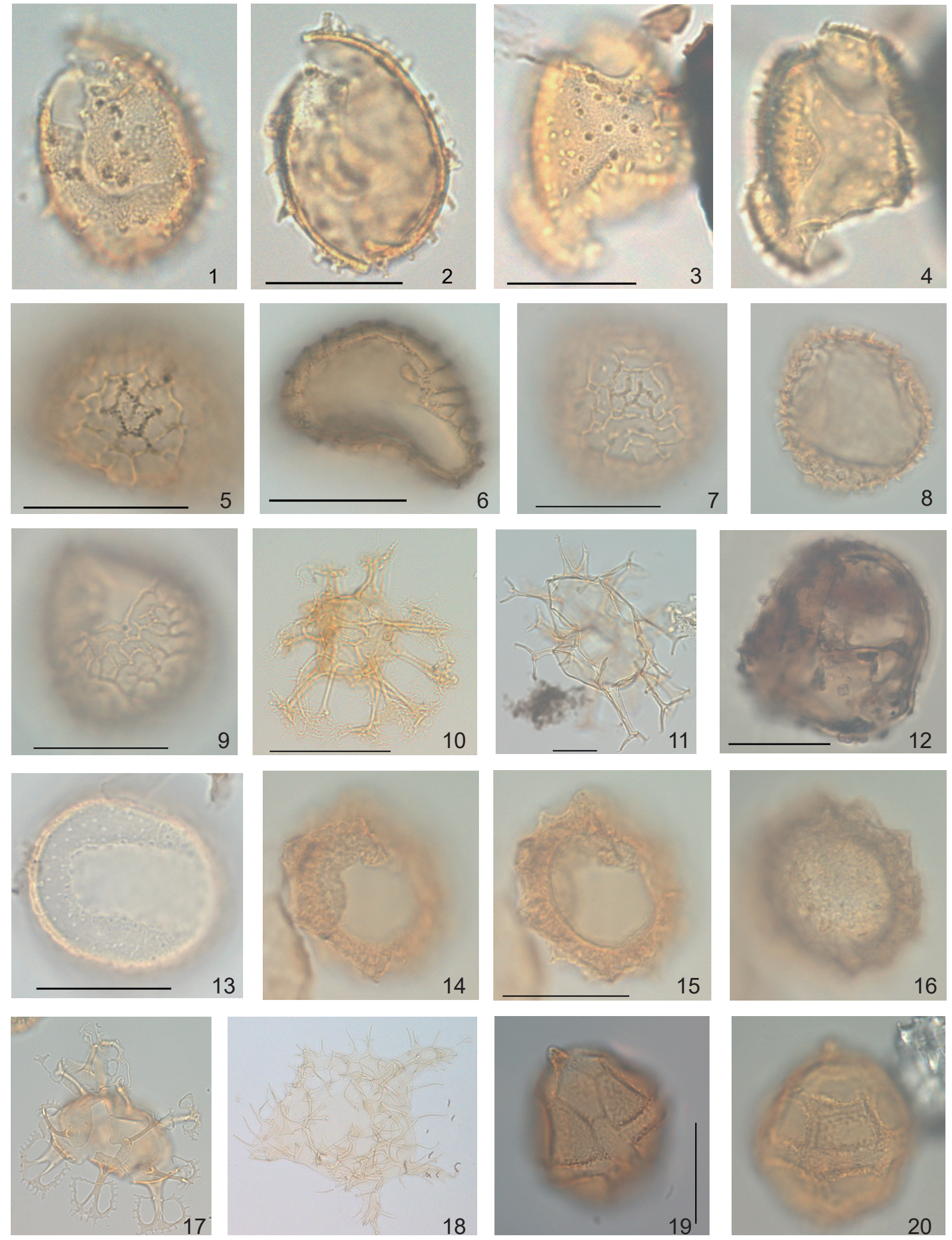

Figure 6. Marine palynomorphs

Dinoflagellate cysts

Operculodinium piaseckii

1, 2. Well 6610/3-1, 460 m, E.F. P52/2.

3, 4. Well 6610/3-1, 502 m, E.F. W15/4.

Pyxidinopsis vesiculata

5, 6. Well 6610/3-1, 525 m, E.F. N35.

7-9. Well 6610/3-1, 611 m, E.F. T70.

Reticulatosphaera actinocoronata

10. Well 6610/3-1, 480 m, E.F. H64/1.
Spiniferites elongatus

11. Well 6610/3-1, 502 m, E.F. V26-3.

cf. Sumatradinium pustulosum

12. Well 6610/3-1, 480 m, E.F. K31/3

Acritarchs

cf. Cyclopsiella granosa

13. Well 6610/3-1, 480 m, E.F. Q35.

Lavradosphaera lucifer

14-16. Well 6610/3-1, 585.8 m, E.F. E16/3.
Reworked Paleogene dinoflagellate cysts Enneadocysta arcuata/pectiniformis 17. Well 6610/3-1, 460 m, E.F. V41/1. Axiodinium augustum

18. Well 6610/3-1, 585.8 m, E.F. U33.

Phthanoperidinium amoenum 19. Well 6610/3-1, 502 m, E.F. V26/1. Phthanoperidinium geminatum 20. Well 6610/3-1, 611 m, E.F. F68/1 

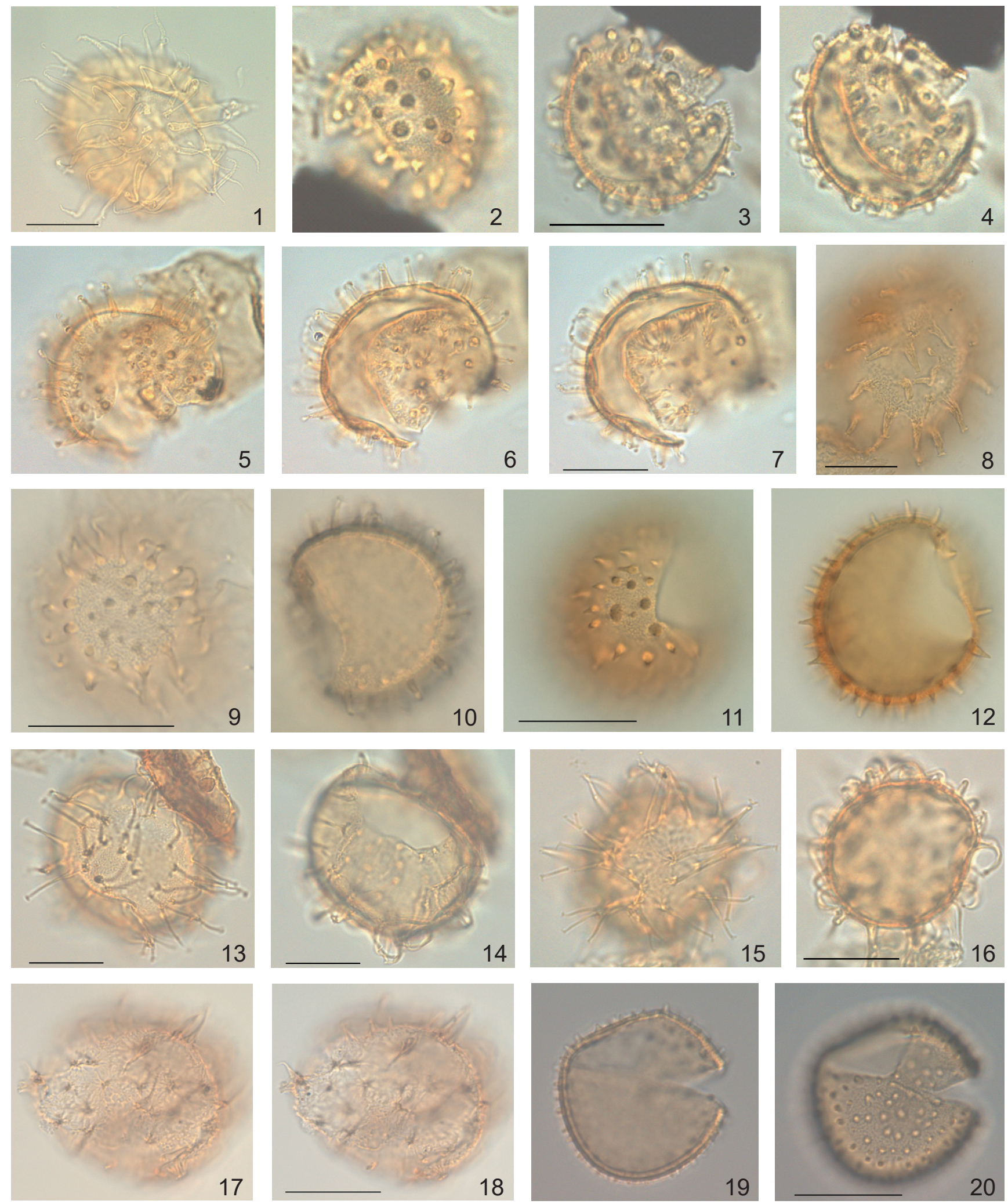

Figure 7. Marine palynomorphs

Dinoflagellate cysts

Lingulodinium machaerophorum

1. Well 6610/3-1, 611 m, E.F. V59/1.

2-4. Well 6610/3-1, 525 m, E.F. X64/2.

Operculodinium israelianum

5-7. Well 6610/3-1, 585.8 m, E.F. W34/3.

$c f$. Lingulodinium machaerophorum

8. Well 6610/3-1, 525 m, E.F. W61/W62.
Operculodinium $s p$.

9, 10. Well 6610/3-1, 525 m, E.F. K51/4.

11, 12. Well 6610/3-1, 502 m, E.F. R37/4.

Operculodinium centrocarpum s.l.

13, 14. Well 6610/3-1, 502 m, E.F. S21/3.

15, 16. Well 6610/3-1, 480 m, E.F. W24/4.

17, 18. Well 6610/3-1, 480 m, E.F. H51/1.
Pyxidinopsis $s p$.

19, 20. Well 6610/3-1, 502 m, E.F. W15/4. 
be exposed to misidentification (Head, 1994). Four specimens of $B$. tepikiense were also recorded at 585.8 m (Fig. 5, photos $18 \& 19$ ). The wall structure of these specimens appear to agree well with the wall structure of the "moderately extreme morphotype" of Van Nieuwenhove (2005). Such 'aberrant' morphtypes are quite rare. All the recorded specimens of $B$. tepikiense in our study have a lower body diameter than that described for the species by Wilson (1973).

Minisphaeridium latirictum appears to be consistent with the species in ODP Site 907 in the Iceland Sea referred to by Schreck et al. (2012) as Cordosphaeridium minimum sensu Benedek \& Sarjeant (1981).

Operculodinium centrocarpum s.l. The specimens included in this taxon include specimens of $O$. centrocarpum (Deflandre \& Cookson) Wall, 1967. There are both small and relatively large forms. This group does not include specimens of cysts of Protoceratium reticulatum (previously known as $O$. centrocarpum sensu Wall \& Dale (1966), see Paez-Reyes \& Head (2013). The latter species is associated with the North Atlantic Drift (Grøsfjeld et al., 2014). Some of the specimens resemble cysts of Protoceratium reticulatum by their small size and delicate processes. However, they deviate from this species by having a microreticulate wall ornamentation.

Operculodinium sp. There are several specimens of Operculodinium sp., which could not be identified to species level. Some of these, referred to as Operculodinium sp., have a spherical to ovoidal central body with a microgranulate wall sculpture (Fig. 7, photos 9-12). They have numerous non-tabular processes (or virgae), which are usually short. These are smooth and formed by the outer wall layer. They taper and are distally acuminate. The processes are open, at least at their base. This species occurs in the foreset sediments of the Molo Formation. Some of the specimens superficially resemble Operculodinium? eirikianum, but differ from this by having a microgranulate wall instead of a microreticulated one.

Pyxidinopsis vesiculata/Cerebrocysta bartonensis. We have recorded several specimens which are in accordance with the description of $P$. vesiculata (Fig. 6, photos 5-9). $P$. vesiculata can be distinguished from $C$. bartonensis by its characteristic small vesicles at the base of some or most of its ridges, forming a fine, complete or incomplete, irregular reticulum over the cyst surface (Head \& Norris, 2003). There are also specimens with less abundant vesicles, and specimens where vesicles are more or less absent. Specimens with these kinds of morphological features have not been reported from the Paleogene previously. Specimens with similar morphology were probably included in the species referred to by Eidvin et al. $(1998,2007)$ as C. bartonensis. As most specimens appear to have vesicles, we have also attributed specimens where the vesicles are nearly absent to $P$. vesiculata.
Spiniferites elongatus. The recorded specimens attributed to $S$. elongatus deviate from the original description of this species by Reid (1974) by having comparatively much longer processes.

Spiniferites spp. Included in Spiniferites spp. are all species of the genus, including Spiniferites mirabilis and Spiniferites ramosus, as well as the undifferentiated species of the genus. Of these, S. mirabilis is occasionally the most abundant species. The group may include both indigenous and reworked specimens.

\section{Results}

\section{General description of the assemblages}

The marine palynomorph assemblages in the analysed section (611-460 m) generally contain many wellpreserved specimens, although the entire range from excellently to poorly preserved varieties has been recorded. The assemblages are strongly dominated by reworked taxa, Paleogene taxa being particularly abundant, although upper Jurassic-lower Cretaceous specimens are also present.

Several stratigraphically significant Neogene dinoflagellate cyst taxa are recorded, although sporadically (Table 2; Electronic Supplement 1). The dating of the Molo Formation in the studied well, presented here, is based on these occurrences, in addition to one acritarch species. Their occurrences in the studied samples are shown in Fig. 4 and include among others; Acomosphaera andalousiensis andalousiensis (a single specimen at $502 \mathrm{~m}$ ), Barssidinium evangelineae (at 460 $\mathrm{m}, 555 \mathrm{~m}$ and $585.8 \mathrm{~m}$ ), Barssidinium graminosum (five specimens recorded at $611 \mathrm{~m}$ ), Barssidinium pliocenicum (a single specimen at $585.8 \mathrm{~m}$ ), B. tepikiense (a single specimen at $460 \mathrm{~m}$ and several specimens at $585.8 \mathrm{~m}$ ), $M$. latirictum (occurring in nearly all the studied samples), Operculodinium piaseckii (a single specimen at $460 \mathrm{~m}$ and $502 \mathrm{~m}$, and Spiniferites elongatus (a single specimen at $502 \mathrm{~m}$ and $460 \mathrm{~m}$ ).

Neogene dinoflagellate cyst taxa that could not confidently be identified to species level are cf. Capillicysta fusca $(480 \mathrm{~m})$, undifferentiated species of Operculodinium, Quinquecuspis sp. (at $480 \mathrm{~m}$ ), and cf. Sumatradinium pustulosum (a single specimen at $480 \mathrm{~m}$ ). Dinoflagellate cysts strongly dominate over acritarchs; the latter occurring in low numbers. One age-significant acritarch, L. lucifer, is recorded (two specimens at $585.8 \mathrm{~m}$ ), in addition to cf. Cyclopsiella granosa (a single specimen at $480 \mathrm{~m}$ ), which may also provide important information. No Neogene taxa have been recorded from the strata below the base of the Molo Formation (at $643 \mathrm{~m}$ ) (Eidvin et al., 2007, unpublished, Karen Dybkjær 2019). 
There are several dinoflagellate cyst species with LO in the Palaeogene but with ranges extending into the Neogene, for example B. micropapillata complex (at $460 \mathrm{~m}$ and $585.8 \mathrm{~m}$ ), Dapsilidinium pseudocolligerum/ pastielsii (at $480 \mathrm{~m}, 502 \mathrm{~m}, 525 \mathrm{~m}, 555 \mathrm{~m}, 585.8 \mathrm{~m}$ and $611 \mathrm{~m}$ ), Hystrichokolpoma rigaudiae (at $460 \mathrm{~m}$, $480 \mathrm{~m}, 555 \mathrm{~m}, 585.8 \mathrm{~m}$ and $611 \mathrm{~m})$, Lingulodinium machaerophorum (at $460 \mathrm{~m}, 502 \mathrm{~m}, 525 \mathrm{~m}, 585.8 \mathrm{~m}$ and $611 \mathrm{~m}$ ), O. centrocarpum (at all depths), P. vesiculata $(480 \mathrm{~m}, 525 \mathrm{~m}, 585.8 \mathrm{~m}$ and $611 \mathrm{~m})$, Reticulatosphaera actinocoronata (at $460 \mathrm{~m}, 480 \mathrm{~m}, 525 \mathrm{~m}$ and $585.8 \mathrm{~m}$ ), Tectatodinium pellitum (at $460 \mathrm{~m}, 480 \mathrm{~m}, 502 \mathrm{~m}, 525 \mathrm{~m}$ and $585.8 \mathrm{~m}$ ) and Operculodinium israelianum. Both $O$. centrocarpum and Spiniferites spp. occasionally occur in significant proportions. The highest occurrence (HO) of some of these taxa, including the B. micropapillata complex, $P$. vesiculata and $R$. actinocoronata, have been used here to constrain the minimum age of the studied succession (Figs. 4 \& 8).

Terrestrial organic material, including spores and pollen, occur abundantly. Bisaccate pollen strongly dominates over spores and non-bisaccate pollen grains. Botryococcus occurs throughout the investigated section. Foraminiferal linings and fungae are also observed, although these are rare (Electronic Supplement 1).

\section{Paleogene and Mesozoic taxa}

The dinoflagellate cyst assemblages in the studied samples are dominated by reworked Paleogene taxa. In addition to long-ranging taxa which may include Paleogene ones, more than 50 Paleogene taxa were identified (Table 2; Electronic Supplement 1). The Paleogene dinoflagellate cyst assemblages are dominated by Areosphaeridium dictyoplokum, Areosphaeridium michoudii, Corrudinium incompositum, Cribroperidinium guiseppei, species of Deflandrea, including Deflandrea phosphoritica, Enneadocysta arcuata/E. pectiniformis and Phthanoperidinium comatum. Other species are Cleistosphaeridium spp., Glaphyrocysta semitecta, Palaeoperidinium pyrophorum, various species of Phthanoperidinium, including Phthanoperidinium geminatum and Spiniferella cornuta, to mention a few. However, it is uncertain whether all of them are Paleogene as, for example, both C. guiseppei and Cleistosphaeridium spp. range well into the Miocene. In addition to these taxa, a number of taxa occur more sporadically, including Axiodinium augustum, C. bartonensis, Diphyes colligerum and Rottnestia borrusica. The proportion of the various Paleogene taxa varies in the different samples.

Upper Jurassic to lower Cretaceous dinoflagellate cysts, including Batioladinium cf. varigranosum, Cribroperidinium granuligerum Group, Gochteodinia villosa villosa, Gonyaulacysta jurassica, Hystrichodinium voigtii, Rhynchodiniopsis cladophora, Scriniodinium pharo, Senoniasphaera jurassica and Sirmiodinium grossii, occur sporadically through the studied interval. However, these are rare compared to the Paleogene taxa.

\section{Discussion}

\section{Age constraints}

The locations of the majority of the sites referred to in the text below are shown in Fig. 9. The recordings of stratigraphically important dinoflagellate cysts and acritarch taxa are listed in Fig. 4. The reported age ranges of these marker taxa are shown in Fig. 8 and are included in Table 3. In the following, the ranges of the marker taxa will be discussed, one by one.

Achomosphaera andalousiensis andalousiensis is a neritic species with a known range from the middle Miocene through upper Pleistocene and Holocene (Head, 1993 and references therein). In Northwest Europe it has its lowest known occurrence in the Serravallian (13.82$11.63 \mathrm{Ma}$ ) (e.g., Powell \& Brinkhuis, fig. 21.2, p. 423, in Lourens et al., 2004). In the eastern Norwegian Sea (Site 643 ) its first reported occurrence was used to define the base of the Achomosphaera andalousiensis Zone, which defines the boundary between the middle and upper Miocene (Manum et al., 1989).

Barssidinium evangelineae ranges from 8.8 to $5.0 \mathrm{Ma}$ in Northwest Europe (Powell \& Brinkhuis, fig. 21.2, p. 423, in Lourens et al., 2004). De Verteuil \& Norris (1996) reported the LO at the base of their DN9 Zone, in the mid-Tortonian. This species was also recorded in the shelf sediments of ODP Hole 911A at the Yermak Plateau in the marginal Arctic Ocean, where its occurrence at c. 5 Ma was consistent with the palaeo-magnetostratigraphy (Grøsfjeld et al., 2014; Mattingsdal et al., 2014).

Barssidinium graminosum and Barssidinium pliocenicum are neritic species with nearly similar total age ranges. They have possibly a range base in the Serravallian (latest middle Miocene) to late Miocene at the Grand Banks, offshore eastern Canada (Lentin et al., 1994), ranging up to the early Pleistocene (De Schepper \& Head, 2008b, 2009). In the eastern North Atlantic they commonly disappear at around $2.6 \mathrm{Ma}$, although they have also been reported from 1.95 My-old shallowmarine deposits in southern England (Head, 1993).

In exploration well 6507/9-5 at the Draugen field, B. graminosum is recorded in ditch-cutting samples from the base of the early Miocene Cordosphaeridium cantharellum Zone of Eidvin et al. (2007) up to $30 \mathrm{~m}$ below the interpreted base of the Naust Formation. However, the occurrences of the species in the lower 


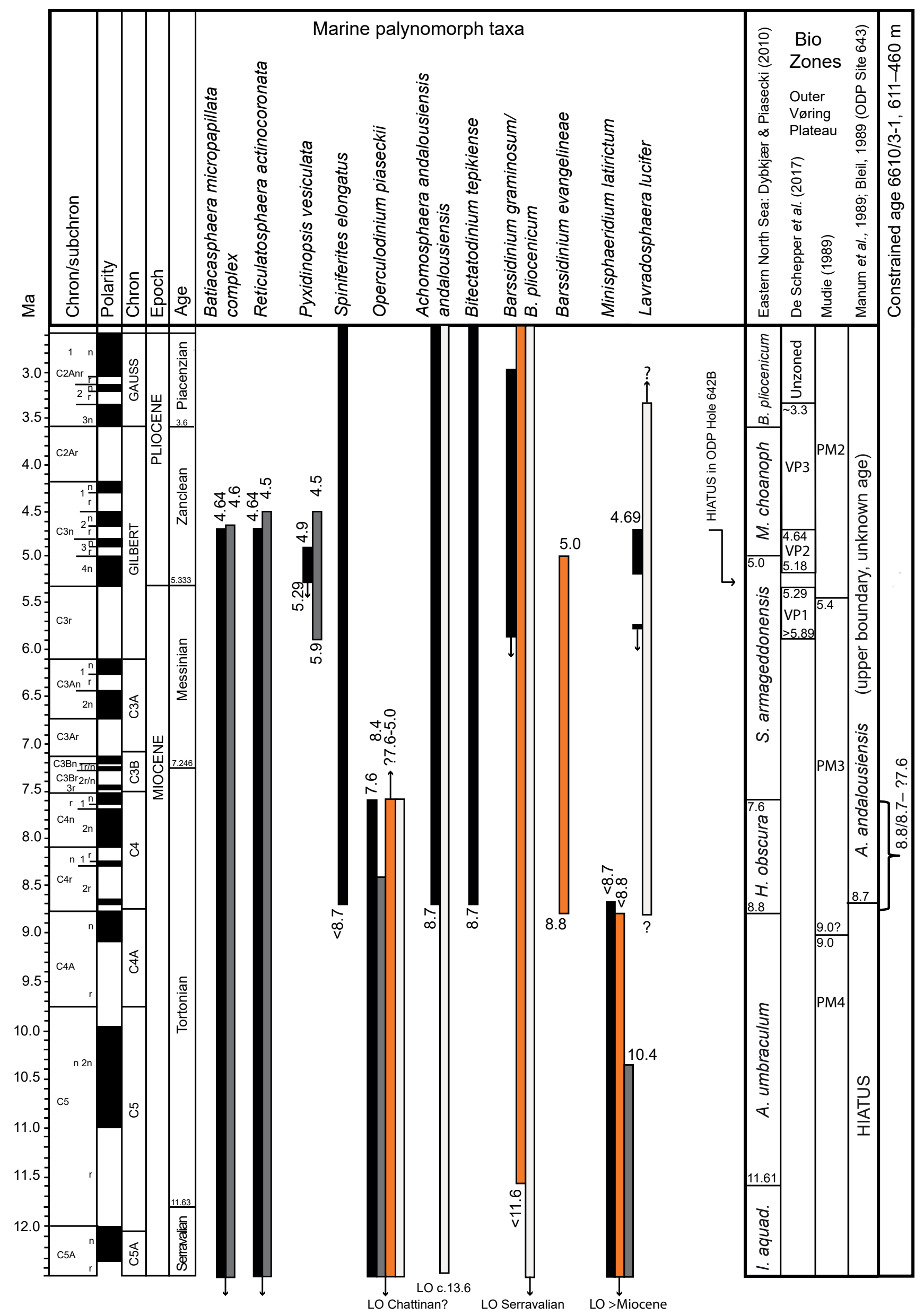


Miocene ditch-cutting samples are possibly due to caving. So far, the oldest known occurrence in sediments of well-calibrated ocean drillcores in the eastern Norwegian Sea is in the Messinian of the ODP Hole 642B (De Schepper et al., 2017). However, this investigation did not study deposits older than 5.89 Ma. In the eastern North Sea it is common in the uppermost Tortonian Selenopemphix armageddonensis Zone (7.6$5.0 \mathrm{Ma})$ (Dybkjær \& Piasecki, 2010). There, it is further consistently recorded in ditch-cutting samples from the Hystrichosphaera obscura Zone (8.8-7.6 Ma) with a few recorded specimens occurring in the Amiculosphaera umbraculatum Zone (11.61-8.8 Ma) (personal observation, Karen Dybkjær).

Rare occurrences of B. pliocenicum occur throughout the ODP Hole 642B section analysed by De Schepper et al. (2017) from c. 5.87-3 Ma. In exploration well 6507/9-5, B. pliocenicum occurs in sediments that are considered to range from a general upper Miocene part of the

Figure 8. Age range of index taxa in the North Atlantic, including the Nordic seas, used to constrain the age of the Molo Formation at Site 6610/3-1. The biozones for the Danish North Sea Basin of Dybkjor \& Piasecki (2010) and for the outer Vøring Plateau, eastern Norwegian Sea, are shown to the right. The latter includes the Messinian to Piacenzian dinoflagellate and acritarch biozones VP1-VP3 of ODP Hole 642B of De Schepper et al. (2017). The mid Miocene to early Pleistocene dinoflagellate cyst zonation of Mudie (1989) (PM1-PM4) and the upper part (i.e. the upper Miocene) of the dinoflagellate zonation of Manum et. al. (1989) are also included. The middle to late Pleistocene biozone Zone PM1 of Mudie (1989) is not shown on the figure. The age of the base of the Achomosphaera andalousiensis andalousiensis Zone is based on the magnetostratigraphy of Bleil (1989). A hiatus (5.29-5.18 Ma) in ODP Hole 642B between the VP1 and VP2 zones is indicated (De Schepper et al., 2015, 2017). Colour code: black - the outer Vøring Plateau, eastern Norwegian Sea; dark grey - Iceland Sea (ODP Hole 907A, Schreck et al. (2012); light grey - Danish North Sea (Dybkjor \& Piasecki, 2010); white - other North Atlantic sites referred to in the text and included in Table 3. The constrained age of the studied section in 6610/3-1 (611 to $460 \mathrm{~m}$ ) is shown to the right. Arrows - taxa with range extending into an older age. Abbreviations: LO - lowest occurrence; I. aquaed - Impagidinium aquaeductus. Ages are based on Cohen et al. (2013, updated 2018).

\section{Colour code}

Vøring Plateau, eastern Norwegian Sea

Iceland Sea

Eastern North Sea

Other sites in the North Atlantic
Achomosphaera sp. 1 Assemblage Zone to the middle part of the lower Pliocene Reticulatosphaera actinocoronata Zone (Eidvin et al., 2007). It is absent in the lowermost part of the Achomosphaera sp. 1 Assemblage Zone, which was assigned an early Miocene age by Eidvin et al. (2007).

The Batiacasphaera micropapillata complex, which is known from the Eocene (Shaw, 1999), ranges up into the Pliocene with $\mathrm{HO}$ between 3.8 and 3.4 Ma throughout the North Atlantic (Schreck et al., 2012 and references therein).

Bitectatodinium tepikiense is recorded consistently from the mid-Langhian (middle Miocene) in the North Atlantic (the Porcupine Basin, southwest of Ireland), while a single specimen was recorded from the Burdigalian (Lower Miocene) (Louwye et al., 2007). In ODP Hole 642C, located in the eastern Norwegian Sea, B. tepikiense has LO in the lowermost Tortonian at the base of the upper Miocene Achomosphaera andalousiensis Zone of Manum et al. (1989). In well $6407 / 9-5$, B. tepikiense has its first reported appearance at $760 \mathrm{~m}$ in the upper part of the upper Miocene Achomosphaera sp. 1 Assemblage Zone of Eidvin et al. (2007). It occurs throughout the remaining investigated sequence, extending into the early Pliocene and younger strata. However, as the analysed samples represent ditchcutting samples we cannot exclude the possibility of $B$. tepikiense being caved.

Minisphaeridium latirictum is commonly recorded from the Miocene across the North Atlantic and adjacent seas, with a highly variable diachronous $\mathrm{HO}$, ranging from the early Serravallian (c.13.1 Ma) to late Tortonian (Schreck et al., 2012 and references therein). In the Iceland Sea (ODP Hole 907A) it has a range top at 10.4 $\mathrm{Ma}$ in the lower Tortonian (Schreck et al., 2012), except for an isolated specimen at 8.4 Ma which is considered reworked. In eastern U.S.A (Salisbury Embayment) it has a reported $\mathrm{HO}$ at c. 10.5 Ma in the lower Tortonian (de Verteuil \& Norris, 1996). In the continental slope off New Jersey (eastern U.S.A.) it disappears in the midTortonian (de Verteuil, 1996). In the Norwegian Sea, this species (referred to as Hystrichosphaeridium latirictum alias Cordosphaeridium minimum) has LO in the late Oligocene Impagidinium sp. 1 Zone (Manum et al., 1989). It is persistently present up to near the top of the upper Miocene Achomosphaera andalousiensis Zone of Manum et al. (1989), at a depth which likely corresponds to the mid-Tortonian. Manum et al. (1989) studied only the lower part of the upper Miocene and could not deduce the exact age of the top of the Achomosphaera andalousiensis Zone. He tentatively correlated it with the Achomosphaera andalousiensis Zone of Piasecki (1980), which was assigned a late Miocene age. Mudie (1989) did not record this species in the Miocene deposits on the Vøring Plateau. In the eastern North Sea, the HO of $M$. latirictum (referred to as Cordosphaeridium minimum) occurs at the upper boundary of the Amiculosphaera 


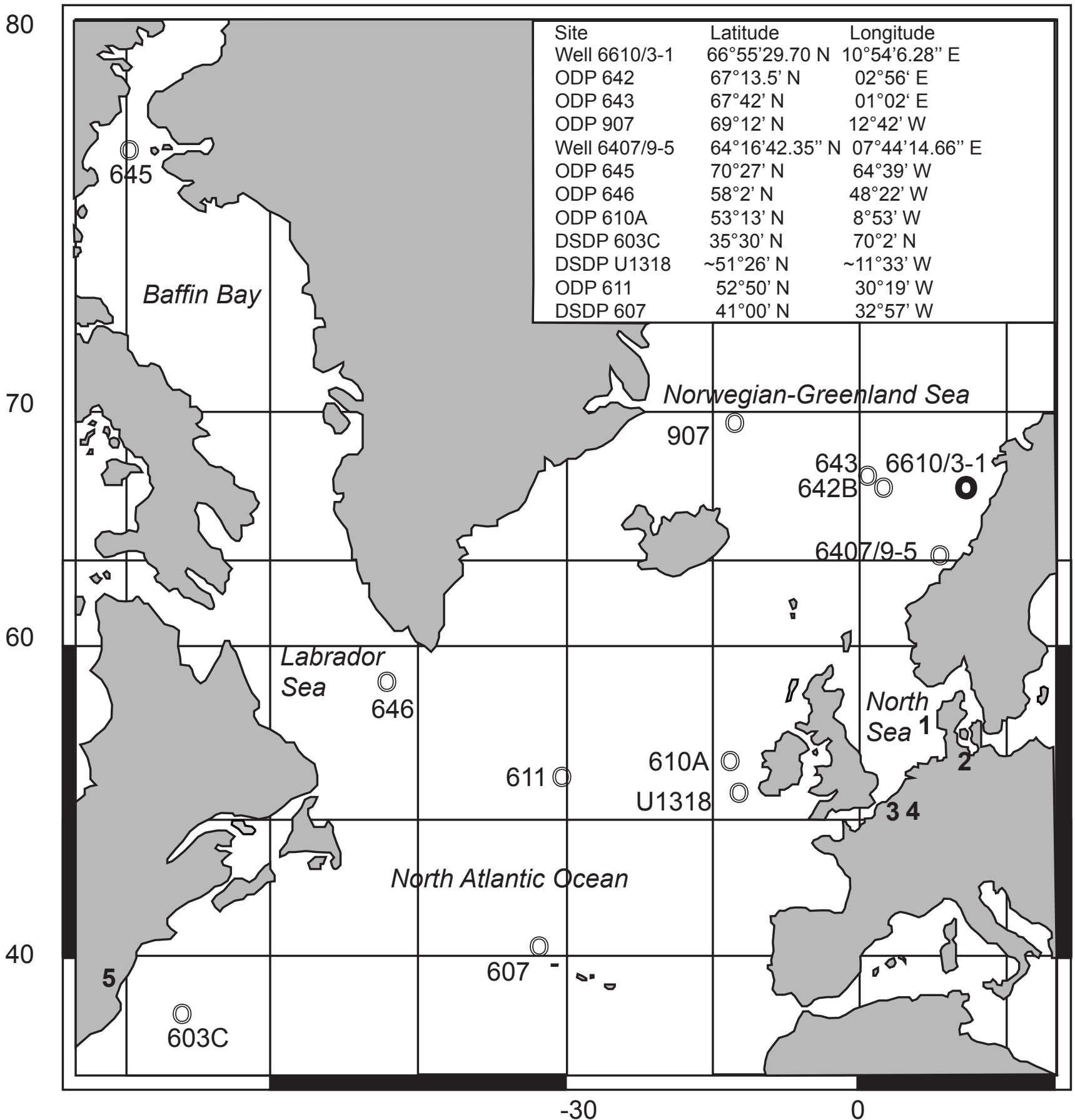

Figure 9. North Atlantic and adjacent basins with locations of sites discussed in the text. Additional discussed sites, indicated by digits, are 1: the Danish North Sea Basin, 2: Northern Germany, 3: Belgium, 4: The Netherlands, 5: the Salisbury Embayment. Redrawn from De Schepper \& Head (2008b).

umbraculum Zone (c. $8.8 \mathrm{Ma}$ ), at the same level as the LO of B. evangelineae (Dybkjær \& Piasecki, 2010). In West Greenland, the $\mathrm{HO}$ of $M$. latirictum was found in the Tortonian in the Qulleq-1 well (Piasecki, 2003) and in the Nuussuaq Basin (Nøhr-Hansen et al., 2002).

Operculodinium piaseckii has been recorded from the earliest Miocene at several sites (de Verteuil \& Norris,
1996 and references therein). In the eastern Norwegian Sea, O. piaseckii is recorded from the lower lower Miocene (Manum et al., 1989). According to Schreck et al. (2012) the $\mathrm{HO}$ of O. piaseckii likely permits correlation across the Nordic seas and North Atlantic over a broader time span within the upper Tortonian. They refer to a number of studies (see references in Schreck et al., 2012) of which the majority indicates ages varying between 8.8 


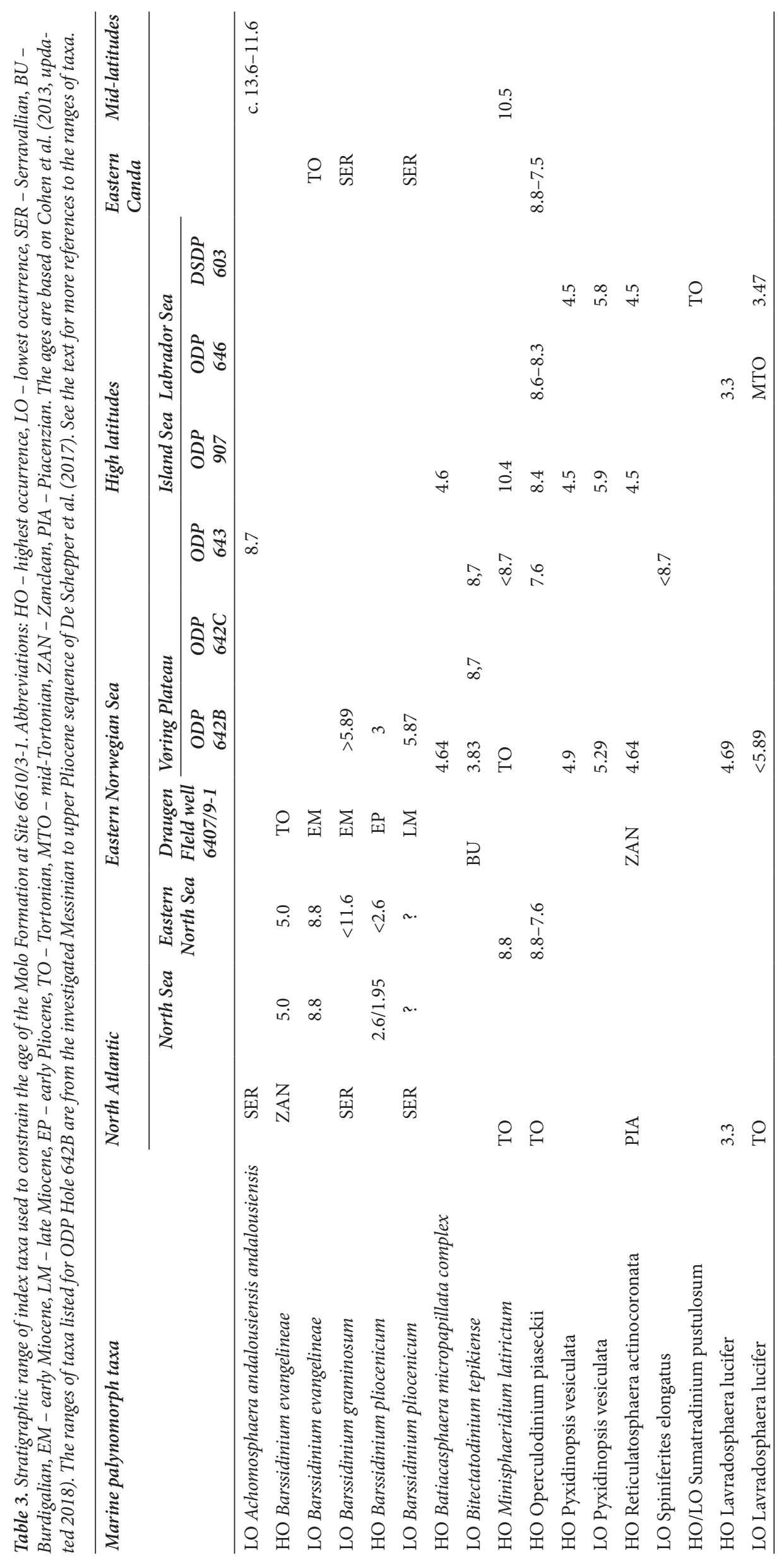


and 7.6 Ma. A few younger recordings are mentioned but these are suggested to be reworked. In the western North Atlantic (Salisbury Embayment, eastern U.S.), O. piaseckii has $\mathrm{HO}$ coincident with Chron C4 (c. 8.8-7.5 Ma) (de Verteuil \& Norris, 1996). In the Labrador Sea (ODP Hole 646B), it has $\mathrm{HO}$ in the uppermost part of nannofossil zone NN10 (c. 8.6-8.3 Ma) (Head et al., 1989a; Knüttel et al., 1989). In ODP Hole 907A in the Iceland Sea, it has $\mathrm{HO}$ at $8.4 \mathrm{Ma}$ (Schreck et al., 2012). O. piaseckii (referred to as Operculodinium sp. of Piasecki, 1980), was one of the characteristic species in the PM4 Zone of Mudie (1989) at the outer Vøring Plateau (ODP Hole 643A/642B). In ODP Hole 643A this species has a magneto-stratigraphically calibrated $\mathrm{HO}$ at $c .7 .6 \mathrm{Ma}$ (Subchron C4n.1n) (Bleil, 1989; Manum et al., 1989; Mudie, 1989). In West Greenland, the HO of O. piaseckii was found in the upper Tortonian in the Qulleq-1 well (Piasecki, 2003) and in the Nuussuaq Basin (NøhrHansen et al., 2002). Schreck et al. (2012) incorrectly refer the $\mathrm{HO}$ of $\mathrm{O}$. piaseckii in the eastern North Sea to be reported from the Hystrichosphaeropsis obscura Zone (8.8-7.6 Ma). Its last occurrence is reported from the Selenopemphix armageddonensis Zone (7.6-5.0 Ma) of late Tortonian age (Dybkjær \& Piasecki, 2010). However, there is no direct age control on the zonal boundaries in this study.

Pyxidinopsis vesiculata has a well-documented range top in the Zanclean at several sites in the North Atlantic (Schreck et al., 2012 and references therein; De Schepper et al., 2015). In the Iceland Sea (ODP Hole 907A) it has $\mathrm{HO}$ at $4.5 \mathrm{Ma}$ (Schreck et al., 2012), whereas in ODP Hole 642B it has HO at 4.9 Ma (De Schepper et al., 2015, 2017). It was not recorded in the eastern Norwegian Sea by Manum et al. (1989) or Mudie (1989). Due to the sparse records of $P$. vesiculata the range base of this species is poorly mapped. The few investigations include the Labrador Sea (ODP Hole 646B) where it was included within Batiacasphaera/Cerebrocysta? from the Upper Miocene (nannofossil zone NN11b, Knüttel et al., 1989; Head et al., 1989a; Schreck et al., 2012). In western North Atlantic DSDP Hole 603C, it was recorded from $5.8 \mathrm{Ma}$ (Head \& Norris, 2003), which is the approximate base of that study. In the Iceland Sea (ODP 907A) it has a lowest reported occurrence at $5.9 \mathrm{Ma}$ (Schreck et al., 2012; De Schepper et al., 2015). At the outer shelf in the eastern Norwegian Sea, $P$. vesiculata was encountered in a few samples dated to between 5.29 and $4.91 \mathrm{Ma}$ (ODP Hole 642B, Vøring Plateau) (De Schepper et al., 2015, 2017). In all these studies only sporadic occurrences of this species have been observed.

Reticulatosphaera actinocoronata, which ranges from the mid-Oligocene (Benedek \& Sarjeant, 1981), has its range top in the Zanclean across the North Atlantic (Schreck et al. 2012 and references therein; De Schepper et al., 2015). In ODP Hole 907A, R. actinocoronata has $\mathrm{HO}$ at $4.5 \mathrm{Ma}$, whereas in ODP Hole 646B it has $\mathrm{HO}$ at 4.64 Ma (Fig. 3; Schreck et al., 2012).
Spiniferites elongatus. Manum et al. (1989) recorded the LO of S. elongatus in ODP Hole 643A (sample 104A643-8-6), in the uppermost part of their Achomosphaera andalousiensis Zone, at a depth which likely corresponds to mid-Tortonian.

Lavradosphaera lucifer has a documented range from several sites in the North Atlantic and adjacent seas (De Schepper \& Head, 2008a) with a total known range from the mid-Tortonian (calcareous nannofossil zone NN10) into the Piacenzian. In the Labrador Sea (ODP Hole $646 \mathrm{~B}$ ) it ranges from mid-Tortonian to $3.3 \mathrm{Ma}$ (Head et al., 1989a); in Baffin Bay it ranges from late Miocene or Zanclean through Piacenzian (de Vernal \& Mudie, 1989; Anstey, 1992); in DSDP Site 611 in the North Atlantic it ranges from the Tortonian through the Zanclean (Mudie, 1987); in the western North Atlantic (DSDP Hole 603C) it ranges from Messinian to $3.47 \mathrm{Ma}$ (Head \& Norris, 2003). In ODP Hole 642B it occurs at the base of the succession ( $>5.89 \mathrm{Ma}$ ), disappearing at $4.69 \mathrm{Ma}$ close to the top of the VP2 Zone (De Schepper et al., 2015, 2017). L. lucifer was not reported by Mudie (1989) or Manum et al. (1989) in the eastern Norwegian Sea. Its true range base is probably not known as its reported LO in most studies represent the age of the base of the studied sections.

\section{Interpreted depositional age}

\section{Neogene age}

Several taxa (e.g., A. andalousiensis andalousiensis, $B$. evangelineae, B. graminosum, $B$. pliocenicum, $L$. lucifer) with an age range within the Neogene, provide incontrovertible evidence for a Neogene age (see above). There are no taxa characteristic for the early and middle Miocene. This indicates no reworking from the early and middle Miocene, and hence no deposition of sediments from this time period. Exceptions are B. graminosum and $B$. pliocenicum, recorded in the lowermost part of the investigated section, and A. andalousiensis andalousiensis (at $502 \mathrm{~m}$ ). These three taxa are known to range down into the late middle Miocene (Serravalian) (see above). Thus, there is a Serravallian maximum age constraint for the Molo Formation on the inner continental shelf off Vestfjorden.

Based on several species (B. evangelineae, $B$. micropapillata complex, $P$. vesiculata, $R$. actinocoronata) with well-constrained $\mathrm{HO}$ within the Zanclean in the Nordic seas and/or at other sites in the North Atlantic, listed above, we can exclude any age of the investigated section younger than the Zanclean. This is supported by the absence of a range of taxa characteristic for the VP2 Zone (5.18 Ma-4.64 Ma) of De Schepper et al. (2017). This includes Filisphaera filifera with a range base at $5.18 \mathrm{Ma}$ at the base of the VP2 Zone (5.18 Ma-4.64 Ma) of De Schepper et al. (2017). Whereas F. filifera is nearly consistently present in the investigated sediments 
younger than $5.18 \mathrm{Ma}$ in ODP Hole 642B, it is absent between 5.1 and $>5.89 \mathrm{Ma}$ (which is the age of the base of their studied section). Thus, an earliest Pliocene minimum age of $5.2 \mathrm{Ma}$ and late middle Miocene (Serravallian) can be firmly constrained for the analysed section. This age span can possibly be further restricted, and we present various hypotheses below.

\section{Deposition during the mid- to late-Tortonian}

The first hypothesis suggests that the analysed section started to accumulate during the mid- to late-Tortonian at c. 8.8-8.7 Ma (Fig. 8). For example, B. evangelineae and $M$. latirictum seem to have overlapping first and last occurrences, respectively, in the eastern North Sea at around 8.8 Ma (Dybkjær \& Piasecki, 2010). The assumption of a depositional age around this time implies contemporaneous $\mathrm{LO}$ and $\mathrm{HO}$, respectively, of these two species in the eastern North Sea and the eastern Norwegian Sea. A thermal gradient is anticipated to have existed in the southern Norwegian-Greenland Sea since the late middle Miocene (Fronval \& Jansen, 1996). This probably resulted in a somewhat diachronous distribution of taxa across the Iceland Sea and eastern Norwegian Sea. This was likely less developed between the North Sea region and the eastern Norwegian Sea. Although the north-south temperature gradient seems to have been somewhat reduced compared to the present day (Matthiessen et al., 2009), a proto North Atlantic Drift probably transported warm surface waters northward to the investigated site. The surface water temperatures in the eastern Norwegian Sea and the North Sea region were possibly quite similar, and a diachronous distribution of taxa probably did not exist between these areas.

In the eastern Norwegian Sea (ODP Hole 643A), O. piasecki has a magnetostratigraphically calibrated $\mathrm{HO}$ at c. 7.6 Ma. In the eastern North Sea it has HO between 7.6 and $5.0 \mathrm{Ma}$ (see above). Thus, the investigated section may have been deposited between 8.8 / 8.7 Ma and 7.6 Ma (Fig. 8).

At Site 643 at the outer Vøring Plateau, the LO of $A$. andalousiensis andalousiensis was used to mark the base of the Achomosphaera andalousiensis andalousiensis Zone of Manum et al. (1989), which defines the boundary between the middle and late Miocene. According to the magnetostratigraphy of Bleil (1989), this boundary falls within an unconformity. In ODP Hole 643A there is an unconformity located at around the middle-late Miocene boundary between 14.66 and $8.71 \mathrm{Ma}$, consisting of a series of hiati, representing a total time gap of around $6 \mathrm{Ma}$ (Bleil, 1989). The LO of A. andalousiensis andalousiensis at Site 643 is in the mid-Tortonian at around $8.7 \mathrm{Ma}$. As the sediments which probably hosted its LO have been eroded, the LO of A. andalousiensis andalousiensis at Site 643 probably does not represent its true LO in the eastern Norwegian Sea. Nevertheless, the occurrence of A. andalousiensis andalousiensis at $502 \mathrm{~m}$ in well 6610/3-1 could support the hypothesis of a midTortonian maximum age for the sediments above 502 $\mathrm{m}$ in well 6610/3-1. We then anticipate that erosion off Vestfjorden took place concomitantly with the erosive event around the middle-late Miocene boundary at Site 643 at the Vøring Plateau. This is supported by the marine palynomorph-inferred Serravallian maximum age of the deposits in well 6610/3-1.

In ODP Hole 643C, B. tepikiense has LO at the same stratigraphic depth as $A$. andalousiensis andalousiensis (Manum et al., 1989). The LO of $S$. elongatus was recorded c. $35 \mathrm{~m}$ above the range base of $A$. andalousiensis andalousiens and B. tepikiense (Manum et al., 1989). However, the stratigraphic usefulness of $B$. tepikiense and S. elongatus is restricted. This is partly due to their morphology which is not very distinctive (see taxonomic note).

The assumption of a mid- to late-Tortonian depositional age for the investigated section is supported by the absence of taxa characteristic for the Messinian, except for $P$. vesiculata, which has a reported LO in the Messinian. However, we consider the LO of this species to be uncertain (see below).

Deposition during the Messinian (7.246-5.333 Ma). Another hypothesis suggests that the entire section was deposited during the Messinian. This is based on the occurrence of $P$. vesiculata throughout the analysed sequence, which has its oldest reported occurrence at 5.9 $\mathrm{Ma}$ in the Iceland Sea (Fig. 8). This hypothesis is supported only by the presence of B. pliocenicum, which in the eastern Norwegian Sea has not been recorded in deposits older than the Messinian (see above). Its oldest reported occurrence with firm age control is in the $c .5 .87$ Ma-old deposits in ODP Hole 642B. In exploration well 6507/9-5 it was not recorded in sediments older than the undefined upper Miocene deposits of the Achomosphaera sp. 1 Assemblage Zone (see above). Strontium-isotope ages from foraminifer tests from these deposits provided ages of 5.8 and 5.2 Ma (Eidvin et al., 2007). In ODP Hole $642 \mathrm{~B}$ at the outer shelf (Vøring Plateau) there is a hiatus, which is paleomagnetically dated to $5.29-5.18 \mathrm{Ma}$ (Fig. 8; De Schepper et al., 2015, 2017). This reflects tectonic activity in the region during that time. The upper part of the analysed sections with the clinoforms were likely deposited prior to this period of non-deposition. The hypothesis of a Messinian depositional age for the entire section implies that the potential Tortonian taxa in the analysed well 6610/3-1 section are recycled. The weakness of this hypothesis is that there are no other taxa characteristic for the Messinian than P. vesiculata. The lowest recorded occurrence of $P$. vesiculata at $5.29 \mathrm{Ma}$ near the Miocene-Pliocene boundary in ODP Hole 642B is likely due to the hiatus in this hole (indicated in Fig. 8). Although this species has so far not been reported from deposits older than the Messinian, its range base needs to be better mapped. 


\section{Reworked Paleogene, Jurassic and Cretaceous taxa}

The assemblages throughout the investigated section contain many similar taxa including the common occurrence of $A$. dictyoplokum and the occurrences of C. bartonensis, D. colligerum and R. borrusica. C. bartonensis and R. borrusica indicate a middle Eocene age (Mudge \& Bujak, 1996; Williams et al., 2004; HeilmannClausen \& Van Simaeys, 2005), whereas A. diktyoplokum ranges into the upper Eocene (El Beialy et al., 2019). D. colligerum has also been recorded in the upper Eocene of Germany (El Beialy et al., 2019). The occurrences of A. augustum and Palaeoperidinium pyrophorum demonstrate that deposits from the upper Paleocene and lowermost Eocene contributed to the reworked material although such occurrences are less common. The range of $A$. augustum is restricted to the Sparnacian (earliest Eocene), while $P$. pyrophorum ranges from the Maastrichtian to the upper part of the Selandian (Heilmann-Clausen et al., 1985; Mudge \& Bujak, 1996; Williams et al., 2004). Typically, Oligocene marker species (e.g., Chiropteridium galea, C. lobospinosum, Distatodinium biffii, Spiniferites manumii, Wetzeliella gochtii/symmetrica) have not been recorded. However, several species range up into the Rupelian, e.g,. Areoligera semicirculata, E. arcuata/pectiniforme, Svalbardella cooksoniae, Thalassiphora fenestrata (Heilmann-Clausen \& Van Simaeys, 2005; Sliwinska et al., 2012; Egger et al., 2016). P. geminatum is common at $585.8 \mathrm{~m}$, indicating an age not younger than the Lutetian (Eldrett et al., 2004). This indicates that sediments of middle Eocene age seem to have been reworked at the time when the deposits in the analysed section accumulated.

As mentioned above, Mesozoic taxa have rare occurrences compared with the Paleogene taxa. Details concerning the stratigraphic ranges of the Upper Jurassic to Lower Cretaceous dinoflagellate cysts, listed under results, can be found, for example, in Davey (1982), Heilmann-Clausen (1987) and Riding \& Thomas (1992). The dinoflagellate cyst assemblages thus indicate minor reworking from the Upper Jurassic-Lower Cretaceous, while massive reworking of Paleogene deposits took place.

\section{Depositional history and reconstruction of surface-water conditions}

Our results demonstrate that extensive erosion and redeposition of older sediments most likely took place as a response to an uplift of the hinterland/coastal zone. Although we discuss possible deposition during the Messinian, we consider a mid-Tortonian depositional age for the Molo Formation to be more likely. We propose that the unconformity at the base of the studied part of the Molo Formation may correlate with the interval from the Serravallian to the mid-Tortonian and that the Molo Formation started to accumulate at around 8.8 / 8.7 Ma. The entire investigated section, which comprises the lower part of the Molo Formation, possibly accumulated between 8.8 / 8.7 and 7.6 Ma (Fig. 4 ). However, we cannot rule out that the lowermost investigated part below the steep shelf-edge clinoforms may have been deposited between the Serravallian and the mid-Tortonian, whereas the clinoforms started to accumulate at around 8.8/8.7 to 7.6 Ma. The analysed section might comprise several erosional events. For example, there might be a hiatus close to the base of the clinoformal package. The reflector in the lowermost finer-grained part of the analysed section hosting the samples at $611 \mathrm{~m}$ and $585.8 \mathrm{~m}$ appears to climb into the prograding succession eastwards (Fig. 2). This indicates that the onset of the progradation might be older than the constrained age of the Molo Formation in well 6610/3-1 (Figs. 3 \& 4). Therefore, the documented age constraint holds only strictly for the 6610/3-1 well section. Due to the erosional truncation of the Molo Formation towards the east, the time of onset of the progradation of the Molo Formation and its oldest shoreline is not recorded (Fig. 2). The erosional event which marks the base of the Molo Formation (at $643 \mathrm{~m}$ ) in well 6610/3-1 can possibly be correlated with the middle-upper Miocene erosional boundary at Site 643 on the outer Vøring Plateau (Bleil, 1989; Manum et al., 1989).

Although uplift/updoming of the hinterland/coastal zone is considered to be the main causal mechanism for the initiation and rapid progradation of the Molo Formation, a concomitant drop in eustatic sea level may also have influenced the erosion of the source regions and the deposition. Eustatic drop took place several times during the late Miocene. Although the time resolution of the fluctuations in sea level in the late Miocene is relatively poor, with an uncertainty of sea-level drops of up to plus/ minus $1 \mathrm{Ma}$ (Boulila et al., 2011), an eustatic drop of up to a few tens of metres has been observed at $c .11$ and 8.7 Ma (Miller, 2005; Boulila et al., 2011).

Except for B. tepikiense (recorded by a single specimen at $460 \mathrm{~m}$ and by a few specimens at $585.8 \mathrm{~m}$ ), there are no cool surface-water tolerant taxa in well 6610/3-1. All the recorded specimens of B. tepikiense represent the 'aberrant' morphtypes described above. D. pseudocolligerum/pastielsii, $H$. rigaudiae, $L$. machaerophorum, O. centrocarpum, O. israelianum, S. mirabilis and T. pellitum are all listed by De Schepper et al. $(2015,2017)$ as warm-temperate, surface-water tolerant species. L. machaerophorum, which is recorded throughout the analysed sequence, is an extant summerblooming temperate to tropical species. It tolerates a minimum summer SST of $10-12^{\circ} \mathrm{C}$ and winter SST $>0{ }^{\circ} \mathrm{C}$ (Lewis \& Hallett, 1997; Zonneveld et al., 2013). In the North Atlantic it has a distribution south of the Arctic Front (Zonneveld et al., 2013). It occurs along the Norwegian coast up to Trondheimsfjorden, at 62 degrees north (Milzer et al., 2013). This appears to be 
the approximate limit for its northern distribution along the Norwegian coast. The species tends to bloom in regions with a broad salinity range. It has frequently been reported from regions where stratified water masses have developed due to a supply of fresh water from river run off or other sources (Zonneveld et al., 2013). A reduced length of the processes has been observed in relationship to both reduced salinity and elevated salinities and temperatures (Zonneveld et al., 2013). At present, $O$. israelianum is restricted to subtropical, tropical and equatorial regions (Zonneveld et al., 2013). It was reported from the lower Pliocene in ODP Hole 911A at the Yermak Plateau (Mattingsdal et al., 2014; Grøsfjeld et al., 2014). However, we still do not know if this species had somewhat different preferences in the past compared to the present day. Spiniferites spp. is ubiquitous in shelf and particularly shelf-edge sediments. S. mirabilis, which is included in this group, is in places richly represented. B. evangelineae, B. graminosum and B. pliocenicum appear to thrive in shallow neritic environments. They are all recorded from the Scotian Shelf offshore eastern Canada (Lentin et al., 1994) and the Yermak Plateau (Grøsfjeld et al., 2014). B. graminosum and B. pliocenicum are also recorded from neritic environments in the Pliocene of Belgium (Louwye et al., 2004). They are heterotrophic taxa and their occurrence may be due to access to nutrients in the coastal zone rather than being controlled by the surface-water temperature. The paleoecological preferences of $P$. vesiculata are not known. However, it is anticipated to represent an adaptation to more temperate conditions (Shreck et al., 2012). B. tepikiense is restricted to subpolar and temperate regions, where surface-water temperatures during winter and summer are between -2 and $+26.9^{\circ} \mathrm{C}$, and where spring to autumn sea surface salinities are between 17.4 and 39.3 (Zonneveld et al., 2013). Elevated abundances occur only where the spring surface-water salinity exceeds 30.3 , and it requires surface-water salinities $>25.6$. It is absent in regions where the surface-water salinity becomes seasonally reduced by meltwater (de Vernal et al., 1998). S. elongatus has a polar to subtropical distribution and occurs in fullmarine conditions, where the salinity is reduced due to ice melting and/or river discharge. It also thrives near frontal systems (Zonneveld et al., 2013).

Thus, the dominance of taxa tolerating warm temperate surface waters and the apparent absence of species tolerating cool sea surface water, is in accordance with deposition prior to the vigorous reorganisation of the surface-water circulation in the Nordic Seas which took place at c. $4.5 \mathrm{Ma}$ (De Schepper et al., 2015, 2017). The marine palynomorphs indicate that warm temperate surface waters prevailed. L. machaerophorum reflects a supply of freshwater from a riverine source. The reduced process length of some of the specimens is probably a result of the reduced salinity. Also, the specimen of B. pliocenicum at $585.8 \mathrm{~m}$ is represented by very short processes. The reduced salinity was likely due to a humid climate with ample freshwater outflow from rivers.
The palaeocoast was located to the east of Well 6610/3-1. Løseth et al. (2017) assumed a strong current parallel to the coast to have influenced the shelf during the accumulation of the Molo Formation. A large river system apparently supplied the basin with fresh water and sediment. The unfavourable environment may have influenced the morphology of some species. For example, the recorded specimens of B. evangelineae, B. pliocenicum and $B$. tepikiense have much smaller sizes than what is normal for these species. This could represent adaptations to the severe conditions in the coastal zone (high-energetic environment, reduced salinity). However, the main cause for the apparent paucity of indigenous taxa is apparently the high sedimentation rate with rapid accumulation of reworked sediments containing organic material, including reworked marine palynomorphs, diluting the indigenous ones.

\section{Conclusions}

Several marine palynomorphs have been recorded for the first time in well 6610/3-1. Among these are the dinoflagellate cysts $A$. andalousiensis andalousiensis, $B$. tepikiense, B. evangelineae, $B$. graminosum, $B$. pliocenicum, M. latirictum, P. vesiculata, O. piaseckii and S. elongatus, and the acritarch L. lucifer.

The presence of these taxa is incontrovertible evidence for a Miocene age of the Molo Formation, in its northern distribution area off Vestfjorden/Lofoten. This inferred age can be further constrained.

We propose that the Molo Formation started to accumulate in well 6610/3-1 at around 8.8 / 8.7 Ma. The entire investigated section, which comprises the lower part of the Molo Formation, including the lower part of the steep shelf-edge clinoforms, possibly accumulated between 8.8 / 8.7 and 7.6 Ma. However, we cannot rule out the possibility that the lowermost investigated part below the steep shelf-edge clinoforms was deposited between the Serravallian and the mid-Tortonian, whereas the clinoforms started to accumulate at around 8.8 / 8.7 to $7.6 \mathrm{Ma}$. The unconformity at the base of the Molo Formation (at $643 \mathrm{~m}$ ) can possibly be correlated with that at the mid- to late-Miocene boundary at the outer Vøring Plateau (Site 643).

Due to the erosion of the Molo Formation farther to the east of well 6610/3-1, the start of the progradation and the ancient coastlines of the Molo Formation are not preserved. Therefore, the documented age constraint for the Molo Formation holds strictly only for the 6610/3-1 well section.

Our results demonstrate that extensive erosion and redeposition of older sediments took place during the 
accumulation of the Molo Formation. The major part of the reworked dinoflagellate cysts is from the middle and late Eocene, although reworking from other parts of the Paleogene, as well as from the upper Jurassic and lower Cretaceous, have also been recorded. Tortonian deposits may also have been eroded. As there are no taxa characteristic for the early and middle Miocene, we anticipate that there was no accumulation of sediments from this time period on the inner shelf off Vestfjorden. Uplift/updoming of the hinterland/coastal zone is considered to be the main causal mechanism for the accumulation and rapid progradation of the analysed section. However, a concomitant drop in sea level probably also influenced the erosion of the source regions and the depositional regime. The marine palynomorphs reflect a high-energetic environment with a supply of fresh water and sediments from a large river system that drained through the Vestfjorden area. Warm temperate surface-water conditions prevailed.

Acknowledgements. The study is funded by the BASE (BASEment fracturing and weathering on- and offshore Norway - Genesis, age, and landscape development) project through support from Lundin Norway, AkerBP, Wintershall and Maersk (now Total Norway). Sigrid Elvenes (NGU) provided the bathymetric map in Fig. 1. Stijn De Schepper (NORCE), Claus Heilmann-Clausen (Aarhus University), Stephen Louwye (University Bremen), Jens Matthiessen (AWI), Dirk Munsterman (TNO), Stefan Piasecki (GEUS), Michael Schreck (UiT) and Robert Williams (NPD) helped with identification of species. Harald Brekke (NPD) and Martin Head (Brock University) reviewed the manuscript. Helge Løseth (Equinor), Dag Ottesen (NGU), Leif Rise (NGU) and William Helland-Hansen (UiB) contributed in geological discussions. David Roberts (NGU) corrected the language. To all these geoscientists we express our gratitude. We acknowledge the NGU, NPD and GEUS for permission to publish this paper.

\section{References}

Anstey, C.A. 1992: Biostratigraphic and paleoenvironmental interpretation of upper middle Miocene through lower Pleistocene dinoflagellate cyst, acritarch, and other algal palynomorph assemblages from Ocean Drilling Program Leg 105, Site 645, Baffin Bay. MSc thesis, University of Toronto, Toronto, $210 \mathrm{pp}$.

Benedek, P.N. \& Sarjeant, W.A.S. 1981: Dinoflagellate cysts from the Middle and Upper Oligocene of Tönisberg (Niederrheingebiet): a morphological and taxonomic restudy. Nova Hedwigia 35, pp. 313-356.

Bleil, U. 1989: Magnetostratigraphy of Neogene and Quaternary sediment series from the Norwegian Sea: Ocean Drilling Program, Leg 104. In Eldholm, O., Thiede, J., Taylor, E., Bjørklund, K., Bleil, U., Cielsielski, P., Despraries, A., Donally, D., Froget, C., Goll, R., Henrich, R., Jansen, E., Krissek, L., Kvenvolden, K., Lehuray, A., Love, D., Lysne, P., McDonald, T., Mudie, P., Osterman, L., Parson, L., Phillips, J., Pittenger, A., Qvale, G., Schoenharting, G., Viereck, L., Morton, A. and Gibson, I. (eds.): Proceedings of the Ocean Drilling Program, Scientific Results 104, College Station, TX, pp. 829-901.

https://doi.org/10.2973/odp.proc.sr.104.181.1989.
Boulila, S., Galbrun, B., Miller, K.G., Pekar, S.F., Browning J.V., Laskar, J. \& Wright, J. 2011: On the origin of Cenozoic and Mesozoic "third-order" eustatic sequences. Earth-Science Review 109, pp. 94-112. https://doi.org/10.1016/j.earscirev.2011.09.003.

Brekke, H. 2000: The tectonic evolution of the Norwegian Sea Continental Margin with emphasis on the Vøring and Mare Basins. Geological Society of London, Special Publications 167, pp. 327-378. https://doi.org/10.1144/GSL.SP.2000.167.01.13.

Bugge, T., Lien, R. \& Rokoengen, K. 1976: Kartlegging av de prekvartære lag utenfor Møre - Trøndelag $\left(63^{\circ}-65^{\circ} \mathrm{N}\right)$. Continental Shelf Institute, Norway (IKU) publication 69, pp. 1-47.

Bullimore, S., Henriksen, S., Liestøl, F.M. \& Helland-Hansen, W. 2005: Clinoform stacking patterns, shelf-edge trajectories and facies associations in Tertiary coastal deltas, offshore Norway: Implications for the prediction of lithology in prograding systems. Norwegian Journal of Geology 85, pp. 169-187.

Châteauneuf, J.-J. 1980: Palynostratigraphie et paléoclimatologie de l'Eocène supérieur et de l'Oligocène du Bassin de Paris. Mémoires du bureau de recherches géologiques et minières (BRGM) 116, pp. $1-360$.

Cohen, K.M., Finney, S.C., Gibbard, P.L. \& Fan, J.-X. 2013 (updated 2018): The ICS International Chronostratigraphic Chart. Episodes 36, pp. 199-204. https://doi.org/10.18814/epiiugs/2013/v36i3/002.

Davey, R.J. 1982: Dinocyst stratigraphy of the latest Jurassic to Early Cretaceous of the Haldager No. 1 borehole, Denmark. Danmarks Geologiske Undersøgelse Serie B 6, 57 pp.

De Schepper, S. \& Head, M.J. 2008a: New dinoflagellate cyst and acritarch taxa from the Pliocene and Pleistocene of the eastern North Atlantic (DSDP Site 610). Journal of Systematic Palaeontology 6, pp. 101-117. https://doi.org/10.1017/S1477201907002167.

De Schepper, S. \& Head, M.J. 2008b: Age calibration of dinoflagellate cyst and acritarch events in the Pliocene-Pleistocene of the eastern North Atlantic (DSDP Hole 610A). Stratigraphy 5, pp. 137-161.

De Schepper, S. \& Head M.J. 2009: Pliocene and Pleistocene dinoflagellate cyst and acritarch zonation of DSDP Hole 610A, eastern North Atlantic. Palynology 33, pp. 179-218. https://doi.org/10.1080/01916122.2009.9989673.

De Schepper, S. \& Head, M.J. 2014: New late Cenozoic acritarchs: evolution, palaeoecology and correlation potential in high latitude oceans. Journal of Systematic Palaeontology 12, pp. 493-519. https://doi.org/10.1080/14772019.2013.783883.

De Schepper, S., Schreck, M., Beck, K.M., Matthiessen, J., Fahl, K. \& Mangerud, G. 2015: Early Pliocene onset of modern Nordic Seas circulation related to ocean gateway changes. Nature Communications 6, 8 pp. https://doi.org/10.1038/ncomms9659.

De Schepper, S., Beck, K.M. \& Mangerud, G. 2017: Late Neogene dinoflagellate cyst and acritarch biostratigraphy for Ocean Drilling Program Hole 642B, Norwegian Sea. Review of Palaeobotany and Palynology 236, pp. 12-32. https://doi.org/10.1016/j.revpalbo.2016.08.005.

de Vernal, A. \& Mudie, P.J. 1989: Late Pliocene to Holocene palynostratigraphy at ODP Site 645, Baffin Bay. In Srivastava, S.P., Arthur, M.A., Clement, B.M., Aksu, A., Baldauf, J., Bohrman, G., Busch, W., Cederberg, T., Cremer, M., Dadey, K., de Vernal, A., Firth, J., Hall, F., Head, M., Hiscott, R., Jarrard, R., Kaminski, M., Lazarus, D., Monjanel, A.-L., Nielsen, O.B., Stein, R., Thiebault, F., Zachos, J., Zimmerman, H. \& Stewart, S.K. (eds.): Proceedings of the Ocean Drilling Program, Scientific Results 105, Texas A\&M University, College Station, TX, pp. 387-399. https://doi.org/10.2973/odp.proc.sr.105.133.1989.

de Vernal, A., Rochon, A., Turon, J.-L. \& Matthiessen, J. 1998: Organic-walled dinoflagellate cysts: palynological tracers of seasurface conditions in middle to high latitude marine environments. Geobios 30, pp. 905-920. https://doi.org/10.1016/S0016-6995(97)80215-X. 
de Verteuil, L. 1996: Data report: Upper Cenozoic dinoflagellate cysts from the continental slope and rise off New Jersey. In Mountain, G.S., Miller, K.G., Blum, P., Poag, C.W. \& Twichell, D.C. (eds.): Proceedings of the Ocean Drilling Program, Scientific Results 150, College Station, TX, pp. 439-454.

https://doi.org/10.2973/odp.proc.sr.150.007.1996.

de Verteuil, L. \& Norris, G. 1996: Miocene dinoflagellate stratigraphy and systematics of Maryland and Virginia. Micropaleontology 42, supplement viii + 172 pp. https:// doi.org/10.2307/1485926.

Dybkjær, K. \& Piasecki, S. 2010: Neogene dinocyst zonation for the eastern North Sea Basin, Denmark. Review of Palaeobotany and Palynology 161, pp. 1-29.

https://doi.org/10.1016/j.revpalbo.2010.02.005.

Egger, L.M., Sliwinska, K.K., van Peer, T.E., Liebrand, D., Lippert, P.C., Friedrich, O., Wilson, P.A., Norris, R.D. \& Pross, J. 2016: Magnetostratigraphically-calibrated dinoflagellate cyst bioevents for the uppermost Eocene to lowermost Miocene of the western North Atlantic (IODP Expedition 342, Paleogene Newfoundland sediment drifts). Review of Palaeobotany and Palynology 234, pp. 159-185. https://doi.org/10.1016/j.revpalbo.2016.08.002.

Eidvin, T. \& Rundberg, Y. 2007: Post-Eocene strata of the southern Viking Graben, northern North Sea; intergrated biostratigraphic, strontium isotopic and lithostratigraphic study. Norwegian Journal of Geology 87, pp. 391-450.

Eidvin, T., Brekke, H., Riis, F. \& Renshaw, D.K. 1998: Cenozoic Stratigraphy of the Norwegian Sea continental shelf, $64^{\circ} \mathrm{N}-68^{\circ} \mathrm{N}$. Norsk Geologisk Tidsskrift 78, pp. 125-151.

Eidvin, T., Bugge, T. \& Smelror, M. 2007: The Molo Formation, deposited by coastal progradation on the inner Mid-Norwegian continental shelf, coeval with the Kai Formation to the west and the Utsira Formation in the North Sea. Norwegian Journal of Geology 87, pp. 75-142.

Eidvin, T., Riis, F., Rasmussen, E.S. \& Rundberg, Y. 2013: Investigation of Oligocene to Lower Pliocene deposits in the Nordic area. Norwegian Petroleum Directorate Bulletin 10, 59 pp.

Eidvin, T., Riis, F. \& Rasmussen, E.S. 2014: Oligocene to Lower Pliocene deposits of the Norwegian continental shelf, Norwegian Sea, Svalbard, Denmark and their relation to the uplift of Fennoscandia: A synthesis. Marine and Petroleum Geology 56, pp. 184-221. https://doi.org/10.1016/j.marpetgeo.2014.04.006.

El Beialy, S.Y., Head, M.J., El Atfy, H. \& El Khoriby, E.M. 2019: Dinoflagellate cyst evidence for the age and palaeoenvironments of the Upper Eocene-Oligocene Dabaa Formation, Qattara Depression, north Western Desert, Egypt. Palynology 43, pp. 268291. https://doi.org/10.1080/01916122.2018.1434696.

Eldholm, O. \& Nysæther, E. 1968: Seismiske undersøkelser på den norske kontinentalsokkel 1968, del C. Seismological Observatory, University of Bergen, $29 \mathrm{pp}$.

Eldrett, J.S., Harding, I.C., Firth, J.V. \& Roberts, A.P. 2004: Magnetostratigraphic calibration of Eocene-Oligocene dinoflagellate cyst biostratigraphy from the Norwegian-Greenland Sea. Marine Geology 204, pp. 91-127. https://doi.org/10.1016/S0025-3227(03)00357-8.

Fronval, T. \& Jansen, E. 1996: Late Neogene paleoclimates and paleoceanography in the Iceland-Norwegian Sea: evidence from the Iceland and Vøring Plateaus. In Thiede, J., Myhre, A., Firth, J.V., Johnson, G.L. \& Ruddiman, W.F. (eds.): Proceedings of the Ocean Drilling Program, Scientific Results 151, College Station, TX, pp. 455-468. https://doi.org/10.2973/odp.proc.sr.151.134.1996.

Grøsfjeld, K., De Schepper, S., Fabian, K., Husum, K., Baranwal, S., Andreassen, K. \& Knies, J. 2014: Dating and palaeoenvironmental reconstruction of the sediments around the Miocene/Pliocene boundary in Yermak Plateau ODP Hole 911A using marine palynology. Palaeogeography, Palaeoclimatology, Palaeoecology 414, pp. 382-402. https://doi.org/10.1016/j.palaeo.2014.08.028.
Head, M.J. 1993: Dinoflagellate cysts, sporomorphs, and other palynomorphs from the upper Pliocene St. Erth Beds of Cornwall, southwestern England. The Paleontological Society, Memoir 31, pp. 1-62. https://doi.org/10.1017/S0022336000061126.

Head, M.J. 1994: Morphology and paleoenvironmental significance of the Cenozoic dinoflagellate genera Tectatodinium and Habibacysta. Micropaleontology 40, pp. 289-321. https://doi.org/10.2307/1485937.

Head, M.J. \& Norris, G. 2003: New species of dinoflagellate cysts and other palynomorphs from the latest Miocene and Pliocene of DSDP Hole 603C, western North Atlantic. Journal of Paleontology 77, pp. 1-15.

https://doi.org/10.1666/0022-3360(2003)077<0001:NSODCA>2.0.CO;2.

Head, M.J., Norris, G. \& Mudie, P.J. 1989a: Palynology and dinocyst stratigraphy of the Upper Miocene and lowermost Pliocene, ODP Leg 105, Site 646, Labrador Sea. In Srivastava, S.P., Arthur, M.A., Clement, B.M., Aksu, A., Baldauf, J., Bohrman, G., Busch, W., Cederberg, T., Cremer, M., Dadey, K., de Vernal, A., Firth, J., Hall, F., Head, M., Hiscott, R., Jarrard, R., Kaminski, M., Lazarus, D., Monjanel, A.-L., Nielsen, O.B., Stein, R., Thiebault, F., Zachos, J., Zimmerman, H. \& Stewart, S.K. (eds.): Proceedings of the Ocean Drilling Program, Scientific Results 105, Texas A\&M University, College Station, TX, pp. 423-451.

https://doi.org/10.2973/odp.proc.sr.105.135.1989.

Head, M.J., Norris, G., \& Mudie, P.J. 1989b: Palynology and dinocyst stratigraphy of the Miocene in ODP Leg 105, Hole 645E, Baffin Bay. In Srivastava, S.P., Arthur, M.A., Clement, B.M., Aksu, A., Baldauf, J., Bohrman, G., Busch, W., Cederberg, T., Cremer, M., Dadey, K., de Vernal, A., Firth, J., Hall, F., Head, M., Hiscott, R., Jarrard, R., Kaminski, M., Lazarus, D., Monjanel, A.-L., Nielsen, O.B., Stein, R., Thiebault, F., Zachos, J., Zimmerman, H. \& Stewart, S.K. (eds.): Proceedings of the Ocean Drilling Program, Scientific Results 105, College Station, TX, pp. 467-514. https://doi.org/10.2973/odp.proc.sr.105.135.1989.

Heilmann-Clausen, C. 1987. Lower Cretaceous dinoflagellate biostratigraphy in the Danish Central Trough. Danmarks Geologiske Undersøgelse Serie A 17, 89 pp.

Heilmann-Clausen, C. \& Van Simaeys, S. 2005: Dinoflagellate cysts from the middle Eocene to ?lowermost Oligocene succession in the Kysing Research Borehole, Central Danish basin. Palynology 29, pp. 143-204. https://doi.org/10.1080/01916122.2005.9989606.

Heilmann-Clausen, C., Nielsen, O.B. \& Gersner, F. 1985: Lithostratigraphy and depositional environments in the Upper Paleocene and Eocene of Denmark. Bulletin Geological Society of Denmark 33, pp. 287-323.

Henriksen, S. \& Vorren, T.O. 1996: Late Cenozoic sedimentation and uplift history on the mid-Norwegian continental shelf. Global Planetary Change 12, pp. 171-199. https://doi.org/10.1016/0921-8181(95)00019-4.

Knüttel, S., Russel, M.D. \& Firth, J.V. 1989: Neogene calcareous nannofossils from ODP

Leg 105: Implications for Pleistocene paleoceanographic trends. In Srivastava, S.P., Arthur, M.A., Clement, B.M., Aksu, A., Baldauf, J., Bohrman, G., Busch, W., Cederberg, T., Cremer, M., Dadey, K., de Vernal, A., Firth, J., Hall, F., Head, M., Hiscott, R., Jarrard, R., Kaminski, M., Lazarus, D., Monjanel, A.-L., Nielsen, O.B., Stein, R., Thiebault, F., Zachos, J., Zimmerman, H. \& Stewart, S.K. (eds.): Proceedings of the Ocean Drilling Program, Scientific Results 105, Texas A\&M University, College Station, TX, pp. 245-262. https://doi.org/10.2973/odp.proc.sr.105.135.1989.

Lentin, J.K., Fensome, R.A. \& Williams, G.L. 1994: The stratigraphic importance of species of Sumatradinium, Barssidinium and Erymnodinium, Neogene dinoflagellate genera from offshore eastern Canada. Canadian Journal of Earth Science 31, pp. 567-582. https://doi.org/10.1139/e94-050. 
Lewis, J. \& Hallett, R. 1997: Lingulodinium polyedrum (Gonyaulax polyedra) a blooming dinoflagellate. In Ansell, A.D., Gibson, R.N. \& Barnes, M. (eds.): Oceanography and Marine Biology: An Annual Review 35, University College London Press, London, pp. 97-161.

Lourens, L.J., Hilgen, F.J., Laskar, J., Shackleton, N.J. \& Wilson, D. 2004: The Neogene. In Gradstein, F.M., Ogg, J.G. \& Smith, A.G. (eds.): A Geologic Time Scale 2004, Cambridge University Press, Cambridge, pp. 409-430. https://doi.org/10.1017/CBO9780511536045.022.

Louwye, S., Head, M.J. \& De Schepper, S. 2004: Dinoflagellate cyst stratigraphy and palaeoecology of the Pliocene in northern Belgium, southern North Sea. Geological Magazine 141, pp. 353378. https://doi.org/10.1017/S0016756804009136.

Louwye, S., Foubert, A., Mertens, K., Van Rooij, D. \& the IODP Expedition 307 Scientific Party 2007: Integrated stratigraphy and palaeoecology of the Lower and Middle Miocene of the Porcupine Basin. Geological Magazine 145, pp. 1-24. https://doi.org/10.1017/S0016756807004244.

Løseth, H., Kyrkjebø, R., Hilde, E., Wild, R.J. \& Bunkholt, H. 2017: 500 $\mathrm{m}$ of rapid base level rise along an inner passive margin - Seismic observations from the Pliocene Molo Formation, mid Norway. Marine and Petroleum Geology 86, pp. 268-287. https://doi.org/10.1016/j.marpetgeo.2017.05.039.

Manum, S.B., Boulter, M.C., Gunnarsdottir, H., Rangnes, K. \& Scholze, A. 1989: Eocene to

Miocene palynology of the Norwegian Sea (ODP Leg 104). In Eldholm, O., Thiede, J., Taylor, E., Bjørklund, K., Bleil, U., Cielsielski, P., Despraries, A., Donally, D., Froget, C., Goll, R., Henrich, R., Jansen, E., Krissek, L., Kvenvolden, K., Lehuray, A., Love, D., Lysne, P., McDonald, T., Mudie, P., Osterman, L., Parson, L., Phillips, J., Pittenger, A., Qvale, G., Schoenharting, G., Viereck, L., Morton, A. and Gibson, I. (eds.): Proceedings of the Ocean Drilling Program, Scientific Results 104, College Station, TX, pp. 611-662. https://doi.org/10.2973/odp.proc.sr.104.176.1989.

Matthiessen, J., Brinkhuis, H., Poulsen, N. \& Smelror, M. 2009: Decahedrella martinheadii Manum 1997-a stratigraphically and paleoenvironmentally useful Miocene acritarch of the high northern latitudes. Micropaleontology 55, pp. 171-186.

Mattingsdal, R., Knies, J., Andreassen, K., Fabian, K., Husum, K., Grøsfjeld, K. \& De Schepper, S. 2014: A new 6 Myr stratigraphic framework for the Atlantic-Arctic Gateway. Quaternary Science Reviews 92, pp. 170-178.

https://doi.org/10.1016/j.quascirev.2013.08.022.

Miller, K.G., Kominz, M.A., Browning, J.V., Wright, J.D., Mountain, G.S., Katz, M.E., Sugarman, P.J., Cramer, B.S., Christie-Blick, N. \& Pekar, S.F. 2005: The Phanerozoic record of global sea-level change. Science 310, 1293-1298. https://doi.org/10.1126/science.1116412.

Milzer, G., Giraudeau, J., Faust, J., Knies, J., Eynaud, F. \& Rühlemann, C. 2013: Spatial distribution of benthic foraminiferal stable isotopes and dinocyst assemblages in surface sediments of the Trondheimsfjord, central Norway. Biogeosciences 10, pp. 44334448. https://doi.org/10.5194/bg-10-4433-2013.

Mudge, D.C. \& Bujak, J.P. 1996: An integrated stratigraphy for the Paleocene and Eocene of the North Sea. In Knox, R.W.O'B., Corfield, R.M. \& Dunay, R.E. (eds.): Correlation of the Early Paleogene in Northwest Europe, Geological Society Special Publication 101, pp. 91-113.

https://doi.org/10.1144/GSL.SP.1996.101.01.06.

Mudie, P.J. 1987: Palynology and dinoflagellate biostratigraphy of Deep Sea Drilling Project Leg 94, sites 607 and 611, North Atlantic Ocean. In Ruddiman, W.F., Kidd, R.B., Baldauf, J.G., Clement, B.M., Dolan, J.F., Eggers, M.R., Hill, P.R., Keigwin Jr., L.D., Mitchell, M., Phillips, I., Robinson, F., Salehipour, S.A., Takayama, T., Thomas, E., Unsold, G., Weaver, P.P.E. \& Orlofsky, S. (eds.): Deep Sea Drilling Project, Initial Reports 94, US Government Printing Office, Washington, D.C., pp. 785-812. https://doi.org/10.2973/dsdp.proc.94.118.1987.
Mudie, P. 1989: Palynology and dinocyst biostratigraphy of the late Miocene to Pleistocene,

Norwegian Sea; ODP Leg 104, Sites 642 and 644. In Eldholm, O., Thiede, J., Taylor, E., Bjørklund, K., Bleil, U., Cielsielski, P., Despraries, A., Donally, D., Froget, C., Goll, R., Henrich, R., Jansen, E., Krissek, L., Kvenvolden, K., Lehuray, A., Love, D., Lysne, P., McDonald, T., Mudie, P., Osterman, L., Parson, L., Phillips, J., Pittenger, A., Qvale, G., Schoenharting, G., Viereck, L., Morton, A. and Gibson, I. (eds.): Proceedings of the Ocean Drilling Program, Scientific Results 104, College Station, TX, pp. 587-610. https://doi.org/10.2973/odp.proc.sr.104.174.1989.

Nysæther, E., Eldholm, O. \& Sundvor, E. 1969: Seismiske undersøkelser av den norske kontinentalsokkel, Sklinnabanken Andøya. Seismological Observatory, University of Bergen, Technical Report 3, 23 pp.

Nøhr-Hansen, H., Sheldon, E. \& Dam, G. 2002: A new biostratigraphic scheme for the Paleocene onshore West Greenland and its implications for the timing of the pre-volcanic evolution. In Jolley, D.W. \& Bell, B.R. (eds.): The North Atlantic igneous province: stratigraphy, tectonic, volcanic and magmatic processes, Geological Society of London, Special Publication 197, pp. 111-156. https://doi.org/10.1144/GSL.SP.2002.197.01.06.

Ottesen, D., Rise, L., Andersen, E.S., Bugge, T. \& Eidvin, T. 2009: Geological evolution of the Norwegian continental shelf between 61_N and 68_N during the last 3 million years. Norwegian Journal of Geology 89, pp. 251-265.

Paez-Reyes, M. \& Head, M.J. 2013: The Cenozoic gonyaulacacean dinoflagellate genera Operculodinium Wall, 1967 and Protoceratium Bergh, 1881 and their phylogenetic relationships. Journal of Paleontology 87, pp. 786-803. https://doi.org/10.1666/12-103.

Patruno, S. \& Helland-Hansen, W. 2018: Clinoforms and clinoform systems: Review and dynamic classification scheme for shorelines, subaqueous deltas, shelf edges and continental margins. Earth Science Reviews 185, pp. 202-233. https://doi.org/10.1016/j.earscirev.2018.05.016.

Piasecki, S. 1980: Dinoflagellate cyst stratigraphy of the Miocene Hodde and Gram Formations, Denmark. Bulletin of the Geological Society of Denmark 29, pp. 53-76.

Piasecki, S. 2003: Neogene dinoflagellate cysts from Davis Strait, offshore West Greenland. Marine Petroleum Geology 20, pp. 1075-1088. https://doi.org/10.1016/S0264-8172(02)00089-2.

Reid, P.C. 1974: Gonyaulacacean dinoflagellate cysts from the British Isles. Nova Hedwigia, 25, pp. 579-637.

Riding, J.B. \& Thomas, J.E. 1992: Dinoflagellate cysts of the Jurassic system. In Powell, A.J. (ed.): A stratigraphic index of dinoflagellate cysts, British Micropalaeontological Society Publication Series, Chapman \& Hall, The University Press, Cambridge, pp. 7-98. https://doi.org/10.1007/978-94-011-2386-0_2.

Rokoengen, K., Rise, L., Bryn, P., Frengstad, B., Gustavsen, B., Nygaard, E. \& Sættem, J. 1995: Upper Cenozoic stratigraphy on the Mid-Norwegian continental shelf. Norsk Geologisk Tidsskrift 75, pp. 88-104.

Schreck, M., Matthiessen, J. \& Head, M.J. 2012: A magnetostratigraphic calibration of Middle Miocene through Pliocene dinoflagellate cyst and acritarch events in the Iceland Sea (Ocean Drilling Program Hole 907A). Review of Palaeobotany and Palynology 187, pp. 66-94. https://doi.org/10.1016/j.revpalbo.2012.08.006.

Shaw, C.L. 1999: Eocene dinoflagellate cysts of Taiwan. Taiwania 44, pp. 155-201.

Sliwinska, K.K., Abrahamsen, N., Beyer, C., Brünings-Hansen, T., Thomsen, E., Ulleberg, K. \& Heilmann-Clausen, C. 2012: Bio- and magnetostratigraphy of Rupelian-mid Chattian deposits from the Danish land area. Review of Palaeobotany and Palynology 172, pp. 48-69. https://doi.org/10.1016/j.revpalbo.2012.01.008. 
Van Nieuwenhove, N. 2005: An evaluation of the intraspecific morphological variation within the dinoflagellate cyst genus Bitectatodinium, with guidelines for light microscopy determination and introduction to ecophenotypism. PhD thesis, M2 BioPalOc 2004-2005, Ghent University, Belgium, 34 pp.

Zonneveld, K.A.F., Marret, F., Versteegh, G.J.M., Bogus, K., Bonnet, S., Bouimetarhan, I., Crouch, E., de Vernal, A., Elshanawany, R., Edwards, L., Esper, O., Forke, S., Grøsfjeld, K., Henry, M., Holzwarth, U., Kielt, J.-F., Kim, S.-Y., Ladouceur, S., Ledu, D., Chen, L., Limoges, A., Londeix, L., Lu, S.-H., Mahmoud, M.S., Marino, G., Matsuoka, K., Matthiessen, J., Mildenhal, D.C., Mudie, P., Neil, H.L., Pospolova, V., Qi, Y., Radi, T., Richerol, T., Rochon, A., Sangiorgi, F., Solignac, S., Turon, J.-L., Verleye, T., Wang, Y., Wang, Z. \& Young, M. 2013: Atlas of modern dinoflagellate cyst distribution based on 2435 datapoints. Review of Palaeobotany and Palynology 191, pp. 1-197.

https://doi.org/10.1016/j.revpalbo.2012.08.003.

Williams, G.L., Brinkhuis, H., Pearce, M.A., Fensome, R.A. \& Weegink, J.W. 2004: Southern Ocean and global dinoflagellate cyst events compared: index events for the Late Cretaceous - Neogene. In Exon, N.F., Kennett, J.P. \& Malone, M.J. (eds.): Proceedings of the Ocean Drilling Program, Scientific Results 189, pp. 1-98. https://doi.org/10.2973/odp.proc.sr.189.107.2004.

Williams, G.L., Fensome, R.A. \& MacRae, R.A. 2017: The Lentin and Williams Index of fossil dinoflagellates 2017 Edition. American Association of Stratigraphic Palynologists Foundation Contributions Series number 48, $1097 \mathrm{pp}$.

Wilson, G.J. 1973: Palynology of the Middle Pleistocene Te Piki bed, Cape Runaway, New Zealand. New Zealand Journal of Geology and Geophysics 16, pp. 345-354.

https://doi.org/10.1080/00288306.1973.10431363. 